\title{
BEHAVIOR OF ANOPHELES ALBIMANUS WIEDE. AND TARSIMACULATA GOELDI.*
}

JAMES ZETEK,

Entomologist, Republic of Panama.

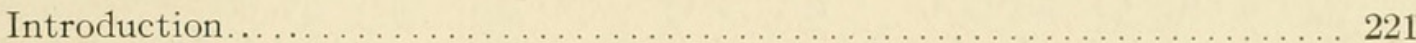

Regional Orientation..................................... 223

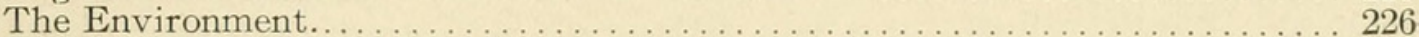

Dynamic Relations of the Mosquitos . . . . . . . . . . . . . . . . . . . . . . . 242

Review of the Salt-marsh Breeding Area . . . . . . . . . . . . . . 242

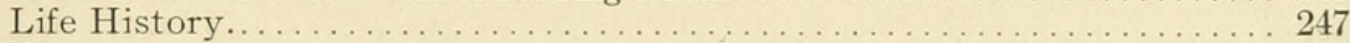

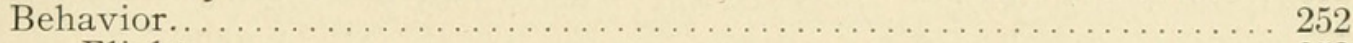

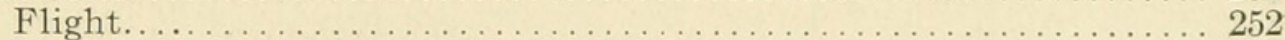

Mosquitos Harboring Under Buildings................... 261

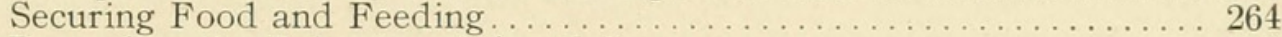

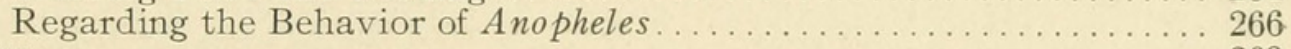

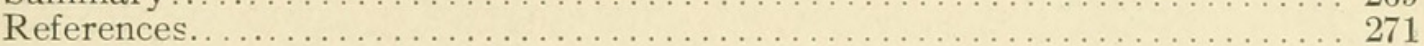

\section{INTRODUCTION}

This paper is largely a report of definitely observed and demonstrated flights of Anopheles albimanus Wiede. and its racial variety tarsimaculata Goeldi. Darling (1912) has shown that these two species are the most important ones in the transmission of malaria on the Canal Zone. Albimanus is by far the commonest Anophelene about settlements, but at times, and locally, the race tarsimaculata appears in large numbers. At the salt-marsh northwest of Gatun, breeding of these two forms was so vigorous (apparently demoralized) that unlimited variations in the middle white band on the palpus were noted, this band being often represented by only a few white scales. For all practical purposes, however, these two forms may be considered as a single species.

\section{PRACTICAL VALUE.}

The answer to the question, aside from a purely scientific importance, "what is the value of the knowledge of the behavior of mosquitos?", is that through this knowledge we are better

*This paper was presented by title at the 1913 meeting, accompanied by a blue-print which gave the essential data concerning the flight studies. While in the interior of Panama, the writer hoped to revise the manuscript, but the mule which carried the packs containing the paper met with an accident while fording a stream and the manuscript was badly spoiled. It had to be rewritten upon the writer's return, from the original notes preserved in his laboratory. Hence this extreme delay.-Z. 
able to direct our crusades of extermination against these common enemies of mankind. To stop the spread of insectborn diseases is to save lives, dollars and to increase comfort.

Environment and organism are so closely knitted together that a change in the former causes a change in the physiological state of the organism. And if the animal cannot endure this change in its abode, it must seek a new, more suitable home, or perish. Thus our knowledge of the behavior of mosquitos gives us clues toward the production of just such changes in the environment of the mosquitos which they cannot withstand. Hence human hand may, by means of relatively simple measures, reduce the population of disease-spreading species far below the critical point of danger, if not actually wipe them out.

But to actually wipe out of existence in a given region all such malefactors would probably be prohibitive on account of its cost. Constant vigilance and effort are required to maintain a humid, tropical area free from malaria or yellow-fever. The conversion of Colon and Panama cities from filth and disease-propagating centers into unusually healthy places, stands out boldly as a proof of what can be done. It means new birth to business opportunities and makes life worth something. The knowledge of the behavior of insects has, therefore, undisputed practical value.

\section{METHODS OF STUDY.}

1. Field Study. This is by far the most productive means of getting at the correct interpretation of the dynamic relations of the mosquitos in their normal environment.

A. By Direct Observation:

i. From a boat, at all times of the day and night.

ii. Observations on land, at the breeding place and townsite, with and without lights, in tents, with domestic animals, etc.

iii. Collection and examination of adult mosquitos.

B. By Experimental Data:

i. Adult mosquitos were attracted into large mosquito-bar nets, at the breeding place, by West Indian negroes. The mosquitos thus caught were sprayed with an aqueous anilin dye (Zetek 1913-a) and liberated at dusk at the same place where sprayed. The mosquitos eaught at the townsite and elsewhere were tested for the presence of color.

ii. By means of intercepting planes, the sides of which were coated with transparent tanglefoot.

2. Laboratory Study. Due to the separaticn of the mosquito from its normal environment, but few laboratory experiments were attempted. These were simple and only to learn the responses to single factors, such as light intensity. 


\section{ACKNOWLEDGMENTS.}

The author is particularly indebted to Surgeon-General, Wm. Crawford Gorgas, formerly Chief Health Officer of the Panama Canal Zone; it is due to his efforts that entomological study on the Isthmus at this time was at all possible. To Mr. Joseph A. Le Prince, formerly Chief Sanitary Inspector, acknowledgments are due for his support and constant encouragements throughout the work.

The author is indebted to the following gentlemen for assistance given: Mr. James B. Shropshire, detailed to assist him; Dr. A. J. Orenstein, former Assistant Chief Sanitary Inspector; Dr. Samuel T. Darling, former Chief of Laboratory, Ancon Hospital; Mr. J. A. Corrigan, Sanitary Inspector at Gatun; Dr. E. Garcon of Gatun Dispensary; Sanitary Inspectors Messrs. C. B. Chinn, Geo. Parker, E. F. Quinby, C. H. Bath, Chas. P. Crafts, A. R. Proctor and S. P. Verner. The writer acknowledges with gratitude the helpful criticisms and encouragements of Dr. L. O. Howard, Chief of the Bureau of Entomology, U. S. Dept. Agric., and of Messrs. August Busck and Frederic Knab of the same bureau. Only those intimately acquainted with mosquitos of tropical America, and who have worked under the enervating strain of its moist, hot climate, can appreciate the services rendered by these gentlemen.

\section{REGIONAL ORIENTATION.}

The Panama Canal Zone is a typical sample of the humid, torrid zone, characterized by an uniformly even climate, with very little seasonal change, with a wet and a dry season, a fairly heavy rainfall, high humidity, prevailing north and northwest winds, and a prolific and luxuriant biota. Of mosquitos alone it yielded about 130 species. For a good account of the Zone and the problems of mosquito control, see Jennings 1912, pp. 131-141.

The town of Gatun is located seven miles from the Atlantic entrance, and is the site of three flights of locks which, in less than a mile, raises the level of water from sea-level to 85 feet in Gatun lake. To sustain this level of 85 feet in the lake, a number of dams had to be built, the largest of them being the famous Gatun Dam, nearly 1.5 miles long and 105 feet high. 
About 0.75 mile west of Gatun, this dam is cut through by a large spillway. Here was located a small camp (Spillway Camp), consisting of several labor barracks, a dispensary and a hotel. A mile north of this place, and nearly a mile northwest of Gatun, is a low, flat land, the highest portion of which is a small dome 20 feet high. The major portion of this region is below the 10 foot contour, most of it a salt-marsh. This region marks the early workings of the old French Canal Company, and is bordered to the east by a deep channel known as the Old French Canal. The excavations of this pre-American attempt were dumped along the banks of this flat land. Thus perfect drainage was made impossible; however, the region never gave serious trouble to the sanitary inspector, until the latter part of 1912 and the beginning of 1913. At this period countless, in fact unbelievable, numbers of Anopheles albimamus Wiede., its racial variety tarsimaculata Goeldi and Aedes tceniorhynchus Wiede., invaded the towns of Gatun and New. Gatun, and it was soon evident that they were breeding in this salt-marsh. It is this area that gave such good opportunities to demonstrate mosquito flight.

East of this marsh is a low island, partly covered with a dense vegetation, and the rest of it composed of barren hydraulic fill. No serious breeding occurred here, however, shade from the hot sun was present for the mosquitos traversing the island. This was the main site for the LePrince experiment recorded in this paper.

South of the island is a small neck of land, mostly above the ten foot contour, which is covered with luxuriant vegetation. This tangle of growth was cut down and burned in February, 1913 , and the measure greatly reduced the number of mosquitos for the time being.

From the breeding place to Gatun is a rise of about ninety feet, but east of the locks the land ranges in height from fifty to a hundred and fifty feet, with isolated knolls of 110 to 160 feet. It is unusually well-drained and oiled, and it can be said that no Anopheles breeds within this treated area-a great credit to the sanitary inspector in charge, J. A. Corrigan.

The population numbered at the time about 4,500, distributed as follows: 800 white Americans, 1000 West Indian negroes, 200 East Indians, 1500 Spaniards and 1000 all others. 
The homes of the Americans are well built, well screened with 18-mesh copper screen, and are raised on concrete posts. Weekly inspections are made of screening and floors and defects, such as holes or cracks through which mosquitos can enter, are quickly repaired. A daily search for mosquitos is made in all barracks by expert negroes and thus many Anopheles are killed before they become dangerous. All doors have self-closing devices.

The quarters of the negro, Spaniard and East Indian are likewise well screened and elevated from the ground. The difference between them and those of the Americans is that more people sleep in labor barracks, and due to the increased perspiration, as well as less body cleanliness, these barracks become veritable traps for mosquitos. Advantage was made of this fact and the "C. H. Bath" mosquito traps were attached to such buildings and through them large numbers of mosquitos were caught.

At New Gatun, a native village adjacent to Gatun proper, the conditions are much the reverse. The dominant figure here is the West Indian, and his home, devoid of screening, rivals in capacity our New York tenements. The population was about six thousand. The only effective anti-malarial measures are free medical aid, good ditches and the ceaseless dripping of larvacides. Orenstein (1912-b) reports three times as much malaria originating in New Gatun as in Gatun proper, and this increase is due to exposures to infection through lack of screening.

In daily habits the people vary greatly. When the day's work is ended, the American usually seeks his only place of amusement - the Y. M. C. A., or he remains in his room. In either case he is fairly well protected from Anophelenes. Saturday nights and Sundays, since the Canal Zone is "dry" territory, he procures his alcoholic preference in Colon or Panama cities, i. e., unless he keeps it in stock in his trunk.

The Spaniard delights to lounge outdoors, remaining so till late at night. Mosquitos find no difficulty in reaching them. The negro likewise prefers to roam about, and this unrest is probably but the natural reaction after a day of hard work. The practice, though, is dangerous. The negro cannot speak through a screen door; he must open it wide, and of course 
must let mosquitos enter until he quits talking. The finding of a greater number of Anophelenes in negro camps is explained by this fact. At Mira Flores the writer found that a negro camp with two doors had almost twice as many mosquitos as did a similar camp with but one door, not-with-standing that the camp with two doors was farthest away from the breeding place.

The time of activity of the men is largely during the daytime, though sometimes forces have worked at night time as well. Men begin to emerge from their barracks as the first rays of the sun greet the new day, and they remain active until the last ray has departed. Mosquito activity is most pronounced during day-break and dusk. This coincidence bears a direct relation to the malarial rate.

\section{THE ENVIRONMENT.}

\section{A. its COMPOSITION.}

In nature the composition and dynamics of the environment are inseparable, but for convenience in the presentation of the subject, this division is necessary.

\section{Physical Factors.}

A. The Wind. For much of the meteorlogical data the writer is indebted to Mr. Wilson and his staff of the Weather Bureau of the Isthmian Canal Commission.

During the months of January, February and March, 1913, the prevailing winds at Gatun were from the north. A summary of the wind movement for January and March is given in table "A". Of the 744 hourly periods in January, 495 showed north winds, and 164 showed northwest winds - a percentage of 66.5 and 22.2 respectively of the total. Many winds reported as "west" or "northeast" were such by the mere addition of a dot or two on the record made by the automatic wind gauge. There were more westerly winds than northeasterly. In the month of March, northeast winds were wholly absent. In other words, the winds are predominantly from the north and northwest. This general prevalence in direction holds true for the entire year in the Atlantic section. 
A. Monthly Wind Movement, Gatun, C. Z.

1. Direction, Hourly Periods.

\begin{tabular}{|c|c|c|c|c|c|c|c|c|c|c|c|c|c|}
\hline \multirow[t]{2}{*}{1913} & \multicolumn{2}{|c|}{ North } & \multicolumn{2}{|c|}{ Northwest } & \multicolumn{2}{|c|}{ West } & \multicolumn{2}{|c|}{$\begin{array}{l}\text { North- } \\
\text { east }\end{array}$} & \multicolumn{2}{|c|}{ East } & \multicolumn{2}{|c|}{ Calms } & \multirow[t]{2}{*}{ Total } \\
\hline & No. & $\%$ & No. & $\%$ & No. & $\%$ & No. & $\%$ & No. & $\%$ & No. & $\%$ & \\
\hline $\begin{array}{l}\text { Jan. . } \\
\text { Mar. }\end{array}$ & $\begin{array}{l}495 \\
540\end{array}$ & $\begin{array}{l}66.5 \\
72.6\end{array}$ & $\begin{array}{l}164 \\
178\end{array}$ & $\begin{array}{l}22.2 \\
23.9\end{array}$ & $\begin{array}{l}57 \\
26\end{array}$ & $\begin{array}{l}7.6 \\
3.5\end{array}$ & 25 & 3.4 & 1 & .01 & 2 & .02 & $\begin{array}{l}744 \\
744\end{array}$ \\
\hline
\end{tabular}

2. Miles per Hourly Periods.

\begin{tabular}{l|c|c|c|c|c|c|c|c|c|c|c|c|r}
\hline Jan.... & 6379 & 68.0 & 1306 & 16.9 & 319 & 3.9 & 170 & 2.1 & 1 & $\ldots$ & $\ldots$ & $\ldots$ & 8175 \\
Mar... & 8655 & 80.7 & 1856 & 17.3 & 217 & 2.0 & $\ldots$ & $\ldots$ & $\ldots$ & $\ldots$ & $\ldots$ & $\ldots$ & 10728 \\
\hline
\end{tabular}

These first three months of the year are within the dry season. This period begins the latter part of December and extends well on into April, though some years it may appear sooner or be much delayed. It is not rainless as the name would imply, for at least every third day some rain falls. But as this dry season advances, the trade winds increase in velocity and become more confined to the north. In March, for instance, there are ten percent more north winds than there were in January; in mileage this was an increase of over eleven percent.

During March, '14, the writer had been in Boquete and David, Chiriqui Province, near Costa Rica. The north winds were so dominant here and of such high velocity that the trees on the plateau leading to Boquete are limbless on the windward side, and their trunks are bent to leeward. Riding on horseback against this fierce wind, along the llanos of Santa Cruz and Dolega, was an experience which cannot be forgotten. Everywhere, everything told of its struggle to remain, even though so powerful a wind aimed at its destruction-presenting a field of intense interest to the ecologist.

A significant feature of these winds is their daily hourly range. The mean wind velocity of the months of January and March is plotted on curve, chart "B". Excepting for differences in velocity, the two curves agree. The crest is at midday. The winds show a steady diminution in velocity from about midnight till about 7:00 a. m., and a like, but more decided decrease from about 2:00 p. m. till about 9:00 p. m. 


\section{B. MEAN WIND VELOCITY. GATUN}

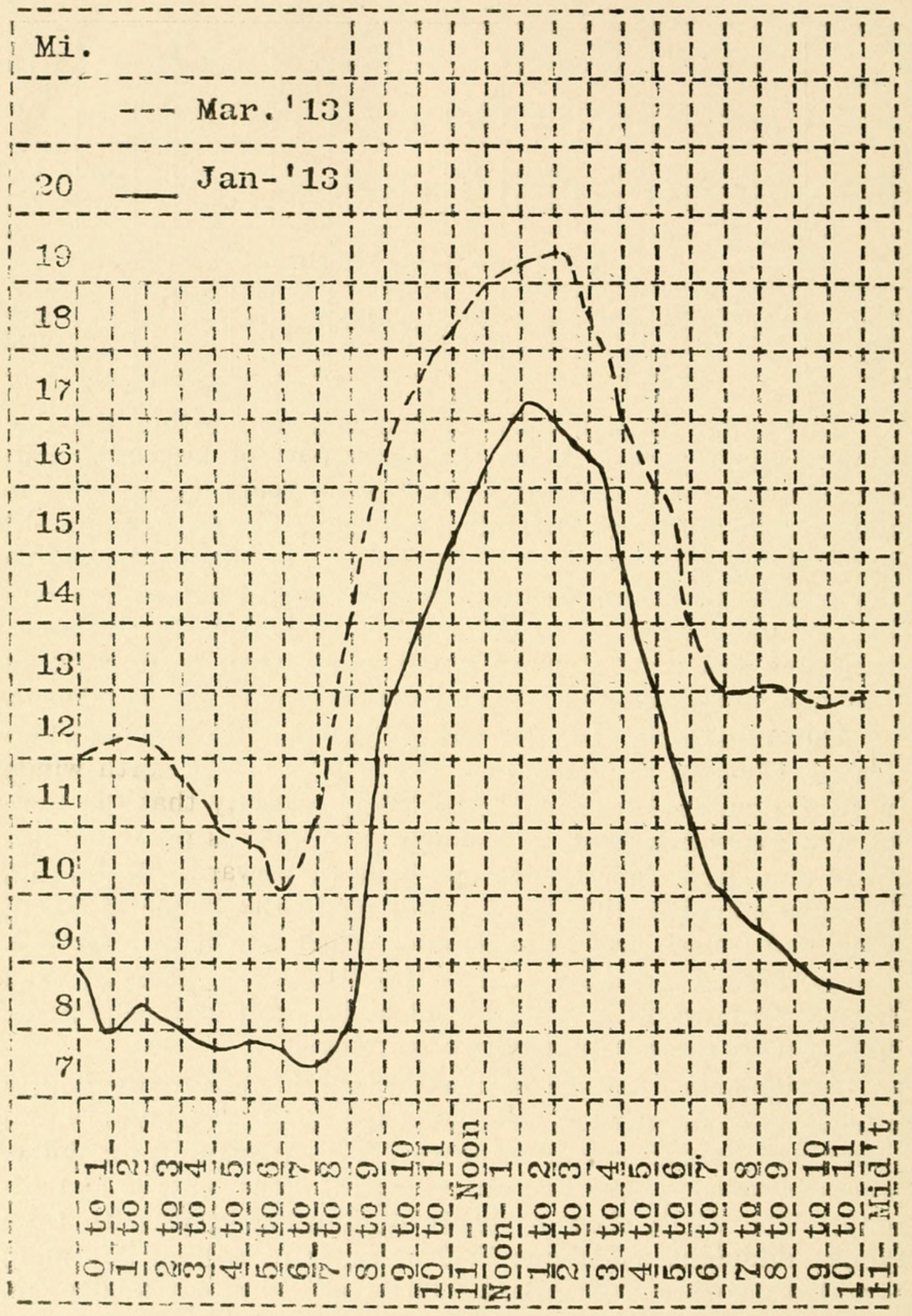


The winds at mid-day are hot, strong and steady. Those at day-break and dusk are much milder, cooler and often inclined to be puffy.

Two charts, "C" and "D" are presented to show the characteristic of the winds at the hours when the mosquitos are most active. These charts give the mileage and direction of winds at Gatun for the hours of four to seven a. m., and five to eight p. m., during the months of Jan., Feb., and March, 1913.

Chart C. Winds, 4-5, 5-6 And 6-7 A. M.

a b $\quad \mathrm{c}$

\begin{tabular}{|c|c|c|c|c|c|c|c|c|c|c|c|c|c|c|c|c|c|c|c|}
\hline Mo. & 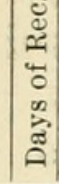 & & $\mathrm{a}$ & $\begin{array}{c}\text { North } \\
\text { b }\end{array}$ & c & & $\begin{array}{c}\text { rthw } \\
\text { b }\end{array}$ & $\begin{array}{l}\text { est } \\
\text { c }\end{array}$ & $\mathrm{a}$ & $\mathrm{b}$ & & $\begin{array}{c}\mathrm{No} \\
\mathrm{ea} \\
\mathrm{a}\end{array}$ & o & c & $\begin{array}{l}\text { Eas } \\
a b\end{array}$ & & $\Xi$ & 胥 & Av. \\
\hline Jan. & 31 & $\begin{array}{l}\text { Days } \\
\text { Miles } \\
\text { Avr. }\end{array}$ & $\begin{array}{r}16 \\
150 \\
9\end{array}$ & $\begin{array}{r}22 \\
200 \\
9\end{array}$ & $\begin{array}{r}21 \\
184 \\
9\end{array}$ & $\begin{array}{l}10 \\
72 \\
7.2\end{array}$ & $\begin{array}{l}6 \\
26 \\
4.5\end{array}$ & $\begin{array}{c}6 \\
29 \\
4.7\end{array}$ & $\begin{array}{l}2 \\
9 \\
4.5\end{array}$ & $\begin{array}{l}2 \\
5 \\
2.5\end{array}$ & $\begin{array}{l}3 \\
10 \\
3.3\end{array}$ & $\begin{array}{l}2 \\
6 \\
3\end{array}$ & $\begin{array}{l}1 \\
3 \\
3\end{array}$ & $\begin{array}{l}1 \\
2 \\
2\end{array}$ & & & & \begin{tabular}{l|}
237 \\
234 \\
225
\end{tabular} & $\begin{array}{l}7.7 \\
7.5 \\
7.3\end{array}$ \\
\hline eb. & 26 & $\begin{array}{l}\text { Days } \\
\text { Miles } \\
\text { Avr. }\end{array}$ & $\begin{array}{r}14 \\
121 \\
9\end{array}$ & $\begin{array}{r}13 \\
115 \\
9\end{array}$ & $\begin{array}{r}15 \\
120 \\
8\end{array}$ & $\begin{array}{c}10 \\
51 \\
5.1\end{array}$ & $\begin{array}{c}10 \\
53 \\
5.3\end{array}$ & $\begin{array}{c}9 \\
39 \\
4.3\end{array}$ & $\begin{array}{l}1 \\
2 \\
2\end{array}$ & $\begin{array}{l}2 \\
6 \\
3\end{array}$ & $\begin{array}{l}2 \\
4 \\
2\end{array}$ & & & & $\begin{array}{l}1 . \\
6 \\
6\end{array}$. & & & \begin{tabular}{l|}
180 \\
174 \\
163
\end{tabular} & $\begin{array}{l}7.0 \\
6.7 \\
6.3\end{array}$ \\
\hline ar. & 31 & $\begin{array}{l}\text { Days } \\
\text { Miles } \\
\text { Avr. }\end{array}$ & $\begin{array}{c}23 \\
288 \\
12.5\end{array}$ & $\begin{array}{r}22 \\
270 \\
12\end{array}$ & $\begin{array}{c}23 \\
265 \\
11.5\end{array}$ & $\begin{array}{r}8 \\
57 \\
7\end{array}$ & $\begin{array}{r}9 \\
67 \\
7\end{array}$ & $\begin{array}{c}8 \\
52 \\
6.6\end{array}$ & & & & & & & & & & $\begin{array}{l}345 \\
337 \\
317\end{array}$ & $\begin{array}{l}11.1 \\
10.9 \\
10.2\end{array}$ \\
\hline
\end{tabular}

Chart D. Winds, 5-6, 6-7 And 7-8 P. M.

a $b$

c

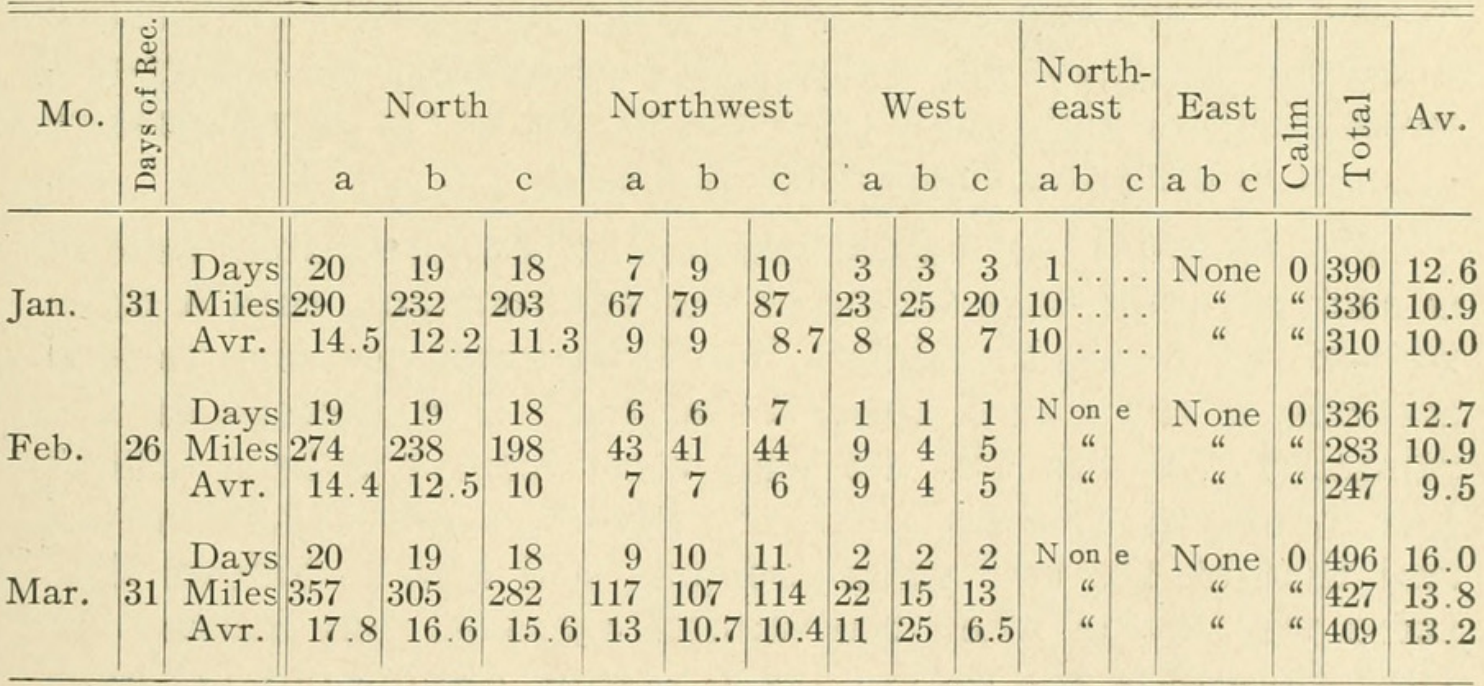


During the entire three months, of the 264 hourly periods in the morning, 196 were with north winds, 76 with northwest winds, and only 19 for all others. Of the same number of evening periods, 170 were with north winds, 72 with northwest and but 22 for all others. In mileage, the north winds were stronger than those of the northwest.

B. Temperature. The Isthmus of Panama lies very near to the thermal equator. Its temperature is fairly even the whole year, ranging from about $95^{\circ} \mathrm{F}$ to $65^{\circ} \mathrm{F}$, the general mean about $80^{\circ} \mathrm{F}$. The greatest daily range of the Gatun section is $10-15^{\circ}$, and this is about $50 \%$ of that of the Central and Pacific sections of the Zone. As the dry season approaches, the maximum and minimum (absolute) temperatures fall gradually, on the average $1.5^{\circ} \mathrm{F}$ within the three months. A steady, though gradual, increase in the maximum and minimum temperature occurs as the dry season begins to merge into the wet season. In the shaded portions of the breeding area it often becomes cool enough at night to demand a blanket for cover, i. e., should one care to sleep there. During the daytime this same locality has a very moist heat, hard to endure.

The great regulator of temperature is the aqueous vapor, (Abbot 1899) "as it is less permeable than dry air to the waves of energy from the sun and still less so to those that radiate from the earth. Its influence in this direction is very important on the Isthmus of Panama because there is only a narrow strip of land between two great oceans, and consequently the relative humidity is always very high. By combining high temperatures with this high humidity there results an excessive absolute amount of moisture in the atmosphere."

C. Rainfall. In humid sections of the torrid zone rainfall is such an important factor of the environment, that a table showing the annual rainfall for three years for the various stations of the Canal Zone is inserted. The average annual rainfall for Gatun for the past nine years has been 129.30 inches, and since the rainfall for 1913 was but 112.81 inches, and that of the two years previous still less, it follows that there were years when the rainfall exceeded 130 inches. In 1913 there were 248 rainy days at Gatun, leaving but 117 days with no rain, i. e., less than four months of clear weather. 
Rainfall of such character exerts great influence upon the environment and its biota. With heat and wind it regulates the environment.

E. Annual Rainfall for Three Years.

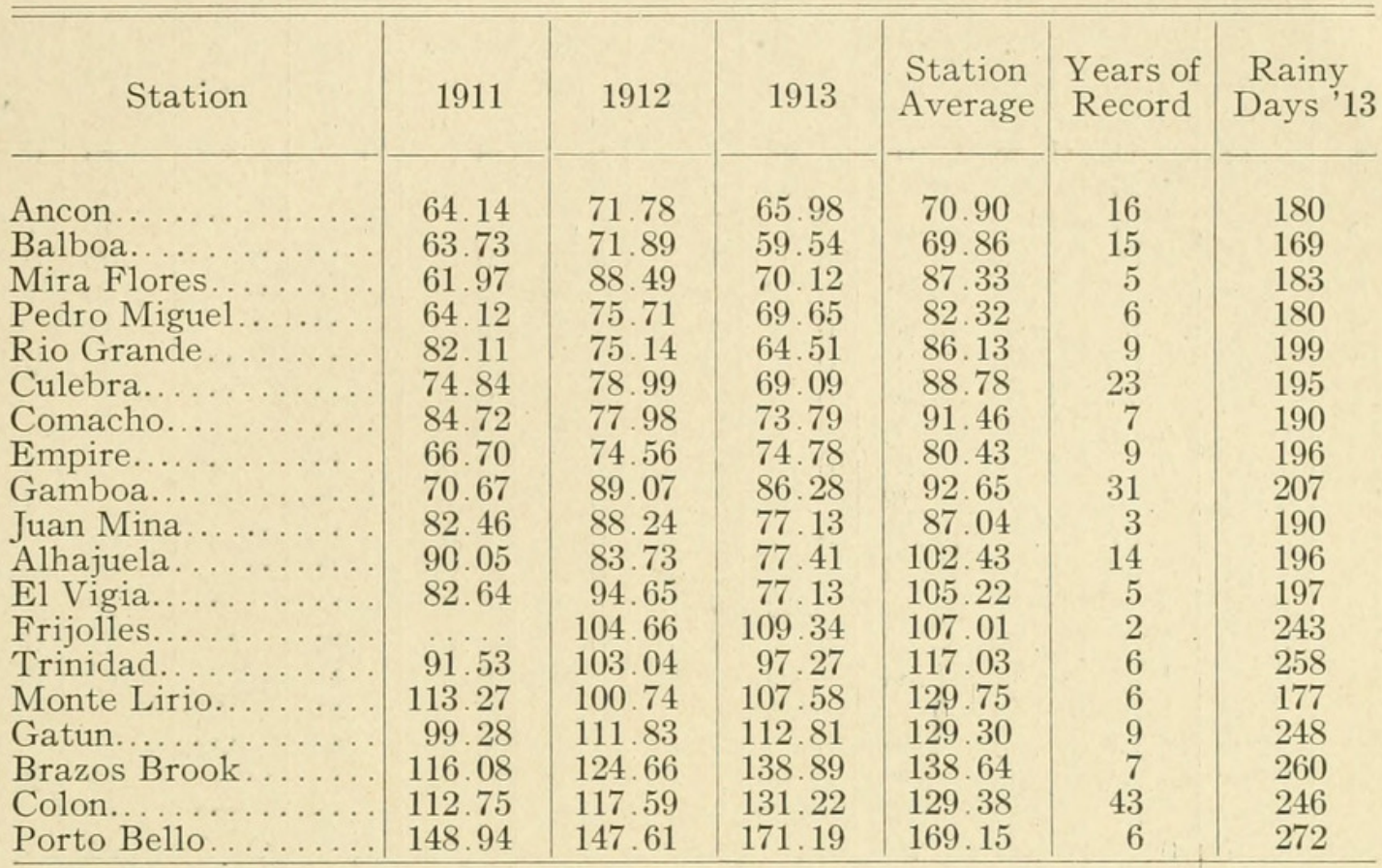

The daily rainfall at Gatun from September, 1912 to September, 1913 is given in table "F". The dry season months of January, February and March show but 38 rainy days out of the 90 of this period. But the rainfall has been less than the average for the station. Only on three days had there been rainfall in excess of one inch. The rains nearly always fall during the afternoon, but it is not unusual to have a mean, drizzling rain all day long, augmented by a changing wind. Thunder storms or violent rains are rare. 
F. Daily Rainfall, Gatun, 1912-1913.

Automatic register; in inches. Values midnight to midnight.

\begin{tabular}{|c|c|c|c|c|c|c|c|c|c|c|c|c|}
\hline Date & p. & ct. & ov. & ec. & an. & eb. & Mar. & pr. & Iay & une & fuly & Iug. \\
\hline $\begin{array}{r}1 \\
2 \\
3 \\
4 \\
5 \\
6 \\
7 \\
8 \\
9 \\
10 \\
11 \\
12 \\
13 \\
14 \\
15 \\
16 \\
17 \\
18 \\
19 \\
20 \\
21 \\
22 \\
23 \\
24 \\
25 \\
26 \\
27 \\
28 \\
29 \\
30 \\
31\end{array}$ & 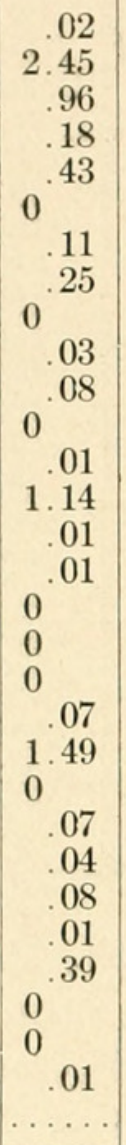 & $\begin{array}{r}.07 \\
.38 \\
.28 \\
.12 \\
.11 \\
1.02 \\
2.04 \\
.26 \\
.02 \\
.06 \\
.14 \\
0 \\
0 \\
.23 \\
.07 \\
.56 \\
0 \\
1.06\end{array}$ & $\begin{array}{r}1.58 \\
.08 \\
1.56 \\
.99 \\
1.18 \\
.35 \\
.31 \\
.44 \\
.96 \\
1.32 \\
.01 \\
0 . \\
.07 \\
.04 \\
.08 \\
.14 \\
.95 \\
.35 \\
.58 \\
.53 \\
.06 \\
.17 \\
.67 \\
.15 \\
.24 \\
1.63 \\
1.54 \\
1.53 \\
1.65 \\
\ldots . .\end{array}$ & $\begin{array}{l}.01 \\
.01 \\
.42 \\
.01 \\
0 \\
0 \\
0 \\
0 \\
0 \\
.30 \\
.26 \\
.08 \\
.51 \\
.01 \\
.13 \\
1.79 \\
2.52 \\
0.03 \\
.34 \\
0.06 \\
.06 \\
.10 \\
.06 \\
.45 \\
.16 \\
0 \\
.03 \\
.26 \\
.02 \\
.16 \\
1.10\end{array}$ & $\begin{array}{l}.20 \\
.15 \\
.22 \\
.04 \\
.44 \\
0 \\
0 \\
.12 \\
0 \\
0 \\
0 \\
0 \\
0 \\
.02 \\
0 \quad \\
.21 \\
.42 \\
0 \\
.04 \\
.01 \\
0 \\
0 \\
.09 \\
0 \\
0 \\
0 \\
0 \\
.23 \\
1.71 \\
0 \\
0 \\
\\
.73 \\
.73\end{array}$ & $\begin{array}{l}.06 \\
.04 \\
.02 \\
0 \\
0 \\
0 \\
0 \\
0 \\
0 \\
0 \\
.01 \\
0 \\
0 \\
.13 \\
.02 \\
.09 \\
1.42 \\
1.07 \\
.01 \\
0 \\
0 \\
0 \\
0 \\
0 \\
\text { T } \\
0 \\
.05 \\
.05\end{array}$ & $\begin{array}{l}\quad .02 \\
.09 \\
0 \\
0 \\
0 \\
{ }^{\mathrm{T}} \\
0.09 \\
.15 \\
0 \\
0 \\
{ }^{\mathrm{T}} \\
0 \\
0 \\
0 \\
0 \\
.03 \\
0 \\
.01 \\
0 \\
\mathrm{~T} \\
.18 \\
.03 \\
0 \\
.17 \\
0 \\
.18 \\
.01 \\
.05 \\
0 \\
0\end{array}$ & $\begin{array}{l}\quad .03 \\
.01 \\
0 \\
0.01 \\
0 \\
0 \\
0 \\
0 \\
0 \\
0 \\
0 \\
0 \\
0 \\
0 \\
0 \\
2.06 \\
.20 \\
0 \\
.07 \\
0 \\
0 \\
0 \\
.05 \\
0 \\
.86 \\
.64 \\
.58 \\
.08 \\
.06 \\
.09 \\
.58 \\
\ldots . .\end{array}$ & $\begin{array}{r}.25 \\
.06 \\
.27 \\
.96 \\
.41 \\
.71 \\
1.39 \\
1.77 \\
.14 \\
.51 \\
.51 \\
.02 \\
.39 \\
.29 \\
.01\end{array}$ & $\begin{array}{r}1.70 \\
.38 \\
.74 \\
.62 \\
1.29 \\
.40 \\
0 \\
0 \\
0 \\
.06 \\
1.55 \\
1.47 \\
.76 \\
.47 \\
0 \\
0 \\
\quad .36 \\
.01 \\
.14 \\
.02 \\
.02 \\
0.09 \\
0.09 \\
0 . \\
0.13 \\
.42 \\
0.05 \\
.05 \\
.02 \\
\ldots . .\end{array}$ & $\begin{array}{c}3.04 \\
.07 \\
0 \quad \\
.46 \\
.63 \\
.36 \\
.06 \\
.18 \\
.43 \\
.02 \\
0 \\
0 \\
0 \\
.11 \\
.69 \\
.08 \\
.20 \\
.19 \\
.02 \\
0 \\
0 \\
.04 \\
1.42 \\
.03 \\
.04 \\
.02 \\
.85 \\
.42 \\
.27 \\
.10 \\
0\end{array}$ & $\begin{array}{l}0 \\
0 \\
.06 \\
0 \\
0.17 \\
.17 \\
1.62 \\
0 \quad \\
.08 \\
.14 \\
3.04 \\
.07 \\
.44 \\
0 \\
0 \\
.45 \\
.18 \\
.35 \\
0 \\
0 \\
.18 \\
.55 \\
2.30 \\
.27 \\
.05 \\
.10 \\
.21 \\
.09 \\
1.78 \\
.15 \\
.01 \\
.03\end{array}$ \\
\hline $\begin{array}{c}1912 \\
\text { Total } \\
1913 \\
\text { Stat'n } \\
\text { Avr. } \\
\text { Excess } \\
\text { ordefi. } \\
\text { Rainy } \\
\text { days }\end{array}$ & $\begin{array}{c}7.84 \\
4.33 \\
9.70 \\
-1.86 \\
21\end{array}$ & $\begin{array}{c}14.52 \\
16.92 \\
16.62 \\
-2.10 \\
25\end{array}$ & $\begin{array}{c}19.18 \\
15.78 \\
22.40 \\
-3.22 \\
29\end{array}$ & $\begin{array}{c}9.82 \\
2.25 \\
13.38 \\
-3.56 \\
24\end{array}$ & $\begin{array}{r}3.92 \\
+.71 \\
15\end{array}$ & $\begin{array}{c}2.92 \\
2.38 \\
2.46 \\
+.46 \\
11\end{array}$ & $\begin{array}{r}1.01 \\
.55 \\
2.70 \\
-1.69 \\
12\end{array}$ & $\begin{array}{r}5.38 \\
4.18 \\
4.20 \\
+1.18 \\
15\end{array}$ & $\begin{array}{c}17.06 \\
13.83 \\
15.82 \\
+1.24 \\
28\end{array}$ & $\begin{array}{c}10.70 \\
14.80 \\
13.39 \\
-2.69 \\
21\end{array}$ & $\begin{array}{r}9.73 \\
11.84 \\
12.08 \\
-2.35 \\
24\end{array}$ & $\begin{array}{c}12.32 \\
11.98 \\
14.09 \\
-1.77 \\
23\end{array}$ \\
\hline
\end{tabular}


D. Humidity. This is the product of heat, wind and water. Humidity is always high on the Zone, though lowest during the dry season. The following table gives the Mean Relative Humidity for the three sections of the Zone, for a period of one year. In the region of Gatun the lowest point reached was $78 \%$, from February to May, and the highest was $89 \%$. Humidity is a powerful agent in the regulation of breeding periods, life duration, time of activity, etc.

G. Mean Relative Humidity (\%) 1912-1913.

\begin{tabular}{c|r|r|r|r|r|r|r|r|r|r|r|r}
\hline & Sep. & Oct. & Nov & Dec. & Jan. & Feb. & Mar & Apr. & May & June & July & Aug. \\
\hline $\begin{array}{c}\text { Ancon (Pacific } \\
\text { section)....... }\end{array}$ & 91 & 93 & 92 & 89 & 87 & 83 & 78 & 76 & 88 & 89 & 90 & 91 \\
$\begin{array}{c}\text { Culebra (Central } \\
\text { section)....... }\end{array}$ & 93 & 93 & 93 & 91 & 89 & 86 & 82 & 80 & 91 & 91 & 91 & 94 \\
$\begin{array}{c}\text { Colon (Atlantic } \\
\text { section)......... }\end{array}$ & 87 & 88 & 89 & 84 & 82 & 78 & 78 & 78 & 87 & 88 & 87 & 89 \\
\hline
\end{tabular}

E. Fogs and Cloudiness. Fogs at Gatun are not numerous and such as do occur are nearly all dissipated by $6: 30$ a. m., and all by $8: 30$ a. m. As the dry season advances, night fogs are fewer in number. Observations at Culebra, Canal Zone, where fogs are of almost daily occurrence, tend to show that they impede the flight of mosquitos. But at Gatun the fogs are all light, not common, and in no way seemed to interfere with the flight of mosquitos.

The dry season is marked by a general absence of clouds, and such as do exist, appear usually in the afternoon. Data is lacking as to what bearing clouds may have upon the environment or organism, but it appears they cannot exert a big influence or else it would have been noted. 
F. Seasonal Changes. The general weather conditions for 1913 are expressed in the following chart:

H. Weather Conditions, Canal Zone, 1913.

Rainfall deficient (except Brazos Brook, Colon and Porto Bello).

Dry season rainfall:

Pacific section $=4 \%$ total.

Central section $=6 \%$ total.

Atlantic section $=10 \%$ total.

March least rain. May most rain.

Air temperature and wind movement slightly above normal.

Atmospheric pressure and cloudiness generally deficient.

\begin{tabular}{|c|c|c|c|c|c|c|c|c|c|c|c|c|c|c|c|}
\hline & \multirow{2}{*}{ 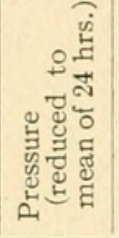 } & \multicolumn{5}{|c|}{ Temperature } & \multirow{2}{*}{ 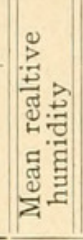 } & \multicolumn{3}{|c|}{ Precipitation } & \multicolumn{5}{|c|}{ Wind Movement } \\
\hline & & ङ & 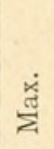 & 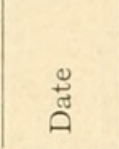 & $\stackrel{\dot{\Xi}}{\dot{\Sigma}}$ & 苞 & & $\begin{array}{l}\stackrel{\Xi}{\Xi} \\
\stackrel{\pi}{0} \\
\stackrel{6}{H}\end{array}$ & 总 & 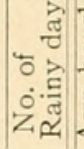 & 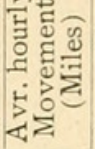 & 青. & 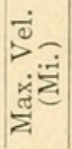 & 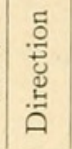 & Aี \\
\hline $\begin{array}{l}\text { Colon... } \\
\text { Culebra } \\
\text { Ancon.. }\end{array}$ & $\begin{array}{l}29.866 \\
29.846 \\
29.834\end{array}$ & $\begin{array}{l}80.1 \\
79.2 \\
80.3\end{array}$ & $\begin{array}{l}91 \\
95 \\
96\end{array}$ & $\begin{array}{l}\text { Jun. } 22 \\
\text { Apr. } 14 \\
\text { Apr. } 27\end{array}$ & $\begin{array}{l}71 \\
64 \\
66\end{array}$ & $\begin{array}{l}\text { Feb. } 4 \\
\text { Jan. } 4 \\
\text { Feb. } 22\end{array}$ & $\begin{array}{l}85 \\
90 \\
87\end{array}$ & $\begin{array}{r}131.22 \\
69.09 \\
65.98\end{array}$ & $\begin{array}{r}129.38 \\
88.78 \\
70.90\end{array}$ & \begin{tabular}{l|}
246 \\
195 \\
180
\end{tabular} & $\begin{array}{r}10.7 \\
7.3 \\
7.2\end{array}$ & $\begin{array}{c}\mathrm{N} \\
\mathrm{NW} \\
\mathrm{NW}\end{array}$ & $\begin{array}{l}36 \\
40 \\
32\end{array}$ & $\underset{\mathrm{N}}{\mathrm{N}}$ & $\begin{array}{l}\text { Nov. } 14 \\
\text { Nov. } 19 \\
\text { Jun. } 11\end{array}$ \\
\hline
\end{tabular}

At a given station, seasonal variation is not marked. But it is evident that at Ancon, where rainy days are one third less than at Colon, and rainfall less than one-half, that a different set of conditions are present there than at Colon.

It is interesting to note that the rainfall for December ' 12 , was generally deficient throughout the Zone, but that at the Colon-Gatun section it was much heavier. Thus the swamp near Gatun which caused so much Anopheles breeding in the early part of 1913 , was prepared for such wide-spread breeding by this increased rain. The influx of pure water meant that the salts in the swamp, which rapid evaporation was about to make stronger, were kept diluted and never became so strong as to inhibit mosquito breeding. It meant also that the density of the water was lowered.

In January, 1913, temperature and relative humidity were above the average. February continued with deficient wind movement. March and April showed also a deficiency in relative humidity and atmospheric pressure. In May these conditions reached their normal. Cloudiness had been deficient throughout the dry season. 
G. Composition of Water. By order of the Chief Sanitary Inspector, daily samples of water from the salt-marsh were sent to the Ancon Hospital laboratory for determination of salt content. After eliminating such samples as appeared untrustworthy, the following table was prepared. All samples were from water where larvæ were numerous.

\section{J. Chlorine Content of Salt-marsh Water.}

Sea-water $=22,000$ parts of $\mathrm{Cl}$ per million.

Port Limon water $=19,000$ parts per million.

$0.022 \%$

$0.019 \%$

MAXIMUM.

\begin{tabular}{|c|c|c|c|}
\hline & $\begin{array}{l}\text { Parts of } \mathrm{Cl} \\
\text { per Million }\end{array}$ & $\begin{array}{c}=\% \text { of Sea } \\
\text { water }\end{array}$ & $\begin{array}{c}=\% \text { of Port } \\
\text { water }\end{array}$ \\
\hline $\begin{array}{l}\text { April } 8 \ldots \\
\text { April } 2 . \\
\text { May } 7 \ldots \\
\text { May } 8 \ldots \\
\text { Feb. } 26 .\end{array}$ & $\begin{array}{l}23,500 \\
21,000 \\
19,083 \\
18,833 \\
18,500\end{array}$ & $\begin{array}{r}107.0 \\
95.0 \\
86.0 \\
85.0 \\
84.9\end{array}$ & $\begin{array}{r}123.7 \\
110.0 \\
100.0 \\
99.0 \\
97.4\end{array}$ \\
\hline Avr. & $\begin{array}{r}20,183 \\
\text { MINIMUM. }\end{array}$ & 90.0 & 105.0 \\
\hline $\begin{array}{l}\text { Feb. } 11 \ldots \\
\text { Feb. } 12 . \\
\text { Feb. } 3 \ldots \\
\text { March } 8 \\
\text { Feb. } 6 \ldots\end{array}$ & $\begin{array}{l}11,250 \\
12,150 \\
12,5 \mathrm{C0} \\
13,500 \\
14,000\end{array}$ & $\begin{array}{l}51.1 \\
60.0 \\
60.0 \\
61.0 \\
63.6\end{array}$ & $\begin{array}{l}60.0 \\
64.0 \\
66.0 \\
71.0 \\
73.0\end{array}$ \\
\hline Avr. & 12,680 & 57.6 & 65.0 \\
\hline
\end{tabular}

General Average:

\begin{tabular}{c|c|c|c|c|c}
\hline Samples & Days & Total Cl & Avr.per Million & $\%$ sea-water & $\%$ Limon water \\
\cline { 2 - 5 } 38 & 27 & 617,480 & 15,817 & 72.0 & 83.0 \\
\cline { 2 - 4 }
\end{tabular}

It is seen that larvæ were breeding in water containing from $55 \%$ to $107 \%$ of ocean salinity, i. e., even in water more saline than the ocean. The density of sea-water is about $2.5 \%$ greater than that of fresh water, and this added buoyancy probably is to the advantage of such larvæ as can thrive in salt waters. Had the salt content been greater, the buoyancy would be too great for the larvæ, besides, the fact that the irritation due to the chemical content would inhibit any extensive breeding. 
Due to the absence of hills, rains could wash no silt into the breeding area, and what was present, settled to the bottom. Imperfect drainage prevented currents, though in time stagnation would follow and make unfit the environment. The latter part of January, 1913, a ditch was cut through the swamp, and shortly after a pipe-line dredge began to pump silt into the swamp. This violent disorder in the environment-current, silt and drainage - soon began to tell upon the numbers of mosquitos breeding in the swamp.

\section{Biotic Factors.}

The microbiology of the waters of the marsh was not studied. Spirogyra and Oscillaria were found within the digestive tract of larvæ of A. tarsimaculata and Aedes taeniorhynchus, but these green algæ can hardly be the only source of food since larvæ of both species have been found in situations devoid entirely of algal growth. The decaying leaves and fallen twigs, excreta of animals and decaying animal matter favor the growth of micro-organisms, and these probably are eaten by the mosquito larvæ.

Trees and shrubbery are important factors because they furnish the needed protection from intense light and heat, and lower the rate of evaporation. So important is this protection to the adult that one never sees these small flies active in the open during the daytime. However, hunger often changes existant physiological states, and so the presence of a man in an exposed place near which mosquitos are hidden, may often bring these toward him in great number; and the first act to be noted is an attempt to sink their proboscis into flesh. But if no human being is present, the mosquitos remain in seclusion. When so venturing forth to secure a blood meal, they show no negative reaction toward heat or light, and may even suffer body mutilations without evident consciousness of pain.

No effort was made to survey the marsh for the animal life it contained, but birds were noted to be the most numerous next to insects, followed by snakes, lizards, iguanas, monkeys and armadillos, the last two rather uncommon. Cows occasionally strayed into the area and when examined on one occasion, were found to have their ears well lined with busy Anopheles and Aedes. 
A species of night-jars (Fam. Caprimulgidæ) has been noted repeatedly at dusk, flying low over the old French Canal, and their actions were those of feeding. This lasted for about an hour, and coincided with the period of mosquito flight. These activities were also noted during dawn, again when mosquito flight was in progress. These night-jars often shifted their position along the Canal, and by row-boat observations it was found that they were where mosquitos were thickest. A shot gun brought down three of these birds and their gullets contained adults of Anophelenes. The stomachs contained in addition ants, hemiptera and a few coleoptera. That these birds were feeding upon the mosquitos is undoubted, but the effect of their ravages was not significant for there seemed to be an infinite source of supply for these mosquitos. Jennings (1908) records a similar case in the Bahamas, the species involved being Chordeiles virginianus minor.

The blood available to mosquitos at the marsh is only such as they can get out of cows, monkeys, birds, lizards, etc., and this is not enough. The fact that these mosquitos flew a mile or more each night to secure rich, human blood, places man among the most important of the biotic factors entering into the mosquito environment. Since the winds from the marsh have been almost wholly from the north or northwest, and not one hour from the southeast, it cannot be argued that the scent of man was born to these mosquitos by the wind and all they had to do was to follow the trail. These mosquitos flew as an air-man does, at a quarter to the wind, and they flew till they found food; it is not at all improbable that they would have flown five miles if Gatun were so distant. Their flight was in quest of food. Here is an example of an animal whose environment is quite scattered.

The question of whether a blood meal is required, or if the mosquitos can live on the juices of fruits, must be answered separately for each species. Of the species treated in this paper, there is no doubt but that they prefer human blood if that is available, and will struggle against many odds in order to get it. Darling (1912) found he could keep adults of Aedes calopus Meigen alive 110 days in captivity by means of raisins and ripe bananas, and Anopheles albimanus alive 12.5 days. The author has noted on several occasions Aedes taeniorhynchus Wiede. feeding on ripe hananas, and once, while searching 
for Thysanoptera, found a male of this species inside of a flower. But if the female mosquitos of these species do eat fruit juices under natural conditions, it appears only fair to believe some one of the able sanitary corp of the Isthmus would have made a few observations of the fact. The infrequency of such observations is explainable on the presumption that human blood is preferred and so soon as a human being is anywhere near, his presence is quickly detected and sought long before he could have found out the whereabouts and doings of these pests. This at least is true of the half dozen common species on the Zone.

Jennings (1912) in his survey of the upper Chagres River valley, did not encounter adults of $A$. albimanus Wiede. nor larvæ, though habitats were seen which if present on the Zone would favor Anopheles breeding. He attributes this absence to the absence of habitations, a presumption fairly accurate. Busck and Orenstein made a trip to the Upper Trinidad valley near Gatun, and but one albimanus was collected by them, though the sylvan Anopheles were abundant. (There is some doubt as to the authenticity of this single albimanus as it may be an accidental mix-up with mosquitos from the Zone.) The writer in his inspections of the Canal Zone, found albimanus to breed only near settlements. It therefore seems quite plausible to believe that the pathogenic species of Anopheles become more and more restricted to human settlements, an adaptation which no doubt will hold for all animals which play a role similar to that of albimanus in the transmission of disease. This trend is probably due to repeated feedings upon human blood, and it may be that the development and establishment of the malarial parasite within the mosquito may have had a tendency toward such isolation. The restricted distribution of Aedes calopus tends to strengthen the idea that pathogenic species cling to inhabited regions.

It also appears that a meal is necessary prior to oviposition. The studies of Darling (1912) indicate such to be the case. The author (1913-c) recorded a case of oviposition in Aedes calopus where prior meal was absent. The fact that the mosquitos concerned in the flight to Gatun returned daily to the marsh, would indicate that food and oviposition were closely linked together. It appears only natural that a mosquito upon emergence from its, pupal prison, should seek, first 
of all, food. While it is true it does not increase in size after emergence excepting as food or eggs swell the abdomen, it does seem that the reproductive organs need further growth, and for this food must be taken. But since the preservation of the species becomes a powerful factor at work within the animal, so starvation and captivity may cause a hurried development of ova. In his dissection of gravid typhoid flies, the writer found more ova in flies which had been fed after emergence from the puparium than in flies totally deprived of food.

The drastic anti-malarial measures of man place him a powerful agent of destruction at work in the environment. Man as an agent hastens or retards natural processes. Thus by means of a ditch and a pipe-line dredge, he has driven the mosquito from its paradise and made its return thereto impossible.

\section{Historic Factors.}

The creation of the salt-marsh habitat can be traced to the work of the old French Canal Company, as already described. When Americans built the big Gatun dam and made the Spillway, they did more than impound the waters of the Chagres. They changed the drainage, tamed the river which often came down in flooding proportions, and by allowing it to peacefully flow past the new Spillway, did away with the annual floods. The floods eliminated, and the increased rainfall in December, 1912, were the prime factors which prepared the marsh for extensive breeding.

\section{B. DYNAMICS OF THE ENVIRONMENT.}

\section{The Habitat of the Immature Stages.}

Larvæ and pupæ were found most frequently associated with green algæ, which plants afford them ample shelter, support and fair protection from fish and larvæ of carnivorous insects. The respiratory tubes of the larvæ were often noted in close proximity to the bubbles of oxygen given off by the algæ. Experimentally, young larvæ (2d moult) were sealed hermetically in a glass jar containing filtered water from the marsh and a small quantity of living algæ; the larvæ developed into adults. Out of the ten larvæ originally placed in the jar, three adults ensued. The time duration was almost twice that under 
normal conditions, but it is clear that growth was maintained because of the exchange of the voided products of respiration by both plant and animal. The balance was easily destroyed by having too many larvæ or too much algæ. This sort of interrelation between organisms is very close in the forms studied, and therein are found the greatest number of points of contact with the environment than elsewhere. Any new factor, or one which is present but is exerting undue activity, stretches the relative balance which existed in the association, and the response caused thereby on the part of the members of the association will be in the direction of the establishment again of a new relative balance. It was quite evident from many observations made that in many ways the larval association was susceptible to quick destruction from such external causes as the presence of silt, wave action, etc.

It was stated that as the dry season approached, the winds increased in velocity, the heat became more intense, and rainfall decreased. The resulting rapid evaporation concentrates the salts in the water of the marsh, changes thereby the density of the water, followed by a change in the microbiology of such a habitat. Such changes usually bring about less mosquito breeding, and on the Canal Zone for many years it has been observed that during the dry season Anopheles pseudopunctipennis Theob. is the dominant Anophelene - a non-transmitter of malaria. The dominant rainy season Anophelene is albimanus. This change in the mosquito fauna is due to habitat changes brought about by the change in the climatic factors. During November and December, 1912, and January, 1913, there was an increase of 14.7 inches of rainfall over the same period the year previous. This increase of pure water at the swamp was sufficient to dilute the salty water to such a degree that subsequent evaporation did not increase the salt-content above a density inhibiting mosquito-breeding. This supposition is strengthened by the fact that in previous years, conditions exactly alike excepting for this increased rainfall during the indicated months, this area caused no influx of mosquitos into Gatun.

Reference was made to the fact that the larvæ from this swamp developed in water which equaled sea-water in chlorine content. The density of such water is 2.5 greater than that of fresh water-a difference sufficient to float chewing gum. Such 
added buoyancy reduces the muscular effort needed to reach the surface, and probably reduces the mortality due to fatigue among the larvæ.

At the laboratory, larvæ of A. tarsimaculata taken from fresh water were transferred into a pan containing saline water from the marsh. This produced intense stimulation and a large mortality resulted. Pupation was accelerated among mature larvæ. The adults that emerged were placed into a large cage containing a plate of fresh water and a plate of salt water, both from actual habitats. A liberal blood meal was given. Eggs were found only in the plate with fresh water. Continuing the experiment, but using pupæ collected at the salt marsh habitat, eggs were deposited in both salt and fresh water. There appears to be a natural selection as to water suitable for oviposition, and in nature such must be the case, for many bodies of water are encountered which appear excellent breeding areas, yet are found wholly devoid of larvæ. At the same time the entire surrounding territory may be literally alive with Anophelenes. When very young larvæ are thrust into saline water, attunement to the rapid change is quicker than when older larvæ are so treated.

The general belief is that Anopheles will not breed in salt water. This is because the average observer fails to learn that the genus Anopheles contains a large number of species which can be grouped into several very distinct sections. The chances are if all Anophelenes bred in the same kind of waters, we would have a far fewer number of species.

DeVogel (1907) found a species of Anopheles breeding in a pool containing $2.8 \%$ of $\mathrm{NaC} 1$; and after considerable study, he arrived at the conclusion that the eggs of species which can live very well in sea-water, develop in such water even when evaporated to one-half its original bulk, but that the larvæ do not appear to transform to adults if the concentration exceeded $33 \%$ of the original quantity. This in the main part is also true of A. tarsimaculata on the Canal Zone. Banks (1908) found Anopheles ludlowii Theob. breeding in both salt and fresh water, quite like tarsimaculata. Howard, Dyar and Knab (1913) criticize Banks' work as inconclusive and believe his fresh-water ludlowii was none other than A. rosii, and there is ample room for such doubt since determinations were made only from larvæ - a difficult task. 
The excrementa of animals living in the swamp, the decay of leaves, branches, carcasses, etc., produce local changes which may prove destructive to larvæ. These larvæ nearly always manage to wriggle away from the influence of such pollution and these chemical changes hardly ever become general enough during the cycle period of the mosquito so as to exterminate all breeding. Even the admixtures of oils and larvacides are found to be difficult, for it is practically impossible to give thorough treatment in all places. The total pollution for the entire season can hardly make the environment unfit for mosquito larvæ. The heavy rains of the next rainy season will again readjust the environment; therefore such pollution can hardly become accumulative.

\section{The Habitat of the Adult.}

The hottest and windiest part of the day is about at noontime, and is the period of least activity in the animal world. It is during dawn and dusk that mosquitos sally forth and show pronounced activity. During the daytime they are hidden in the bush, under buildings, etc. The factors that regulate this time-adaptation are light, heat and wind. Among the factors which disturb the tranquility of the mosquito world, man and his radical measures assume greatest importance. Ditches, oil, hydraulic fills and plenty of patience are the tools that slowly but surely get at the root of such serious breeding and convert it to unfitness for such purpose.

\section{DYNAMIC RELATIONS OF THE MOSQUITOS.}

\section{A. REVIEW OF THE SALT-MARSH BREEDING AREA.}

The early part of January, 1913, the writer was sent to Gatun. The conditions found were really alarming, inasmuch as the species involved was a malaria-transmitter, and the unscreened, congested town of New Gatun invited a spread of malaria. This influx of mosquitos was unexpected and hence unprovided for with funds, but the energetic work of LePrince and Corrigan, aided by several sanitary inspectors, soon brought this danger within control. The following table is introduced to show the number of mosquitos actually caught during the three weekly periods ending February 15, 1913, and the number of reported cases of malaria for the same period. 
K. Anopheles and Malaria, Gatun District.

\begin{tabular}{|c|c|c|c|}
\hline & Feb. 1 & Feb. 8 & Feb. 15 \\
\hline $\begin{array}{l}\text { Trap catch, Gatun................................ } \\
\text { Trap and hand catch, both Gatun and New }\end{array}$ & $\begin{array}{r}1,039 \\
12,067\end{array}$ & $\begin{array}{r}604 \\
11,897\end{array}$ & $\begin{array}{r}387 \\
12,838\end{array}$ \\
\hline Total. . & 13,106 & 12,501 & 13,225 \\
\hline 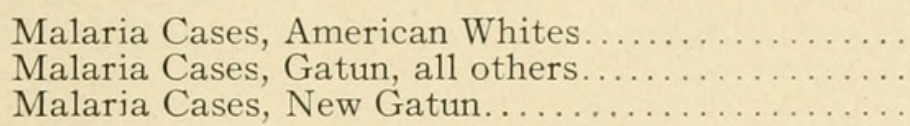 & $\begin{array}{r}5 \\
16 \\
31\end{array}$ & $\begin{array}{r}4 \\
20 \\
33\end{array}$ & $\begin{array}{r}8 \\
19 \\
39\end{array}$ \\
\hline
\end{tabular}

By trap catch is meant those mosquitos which were caught in the "C. H. Bath" mosquito traps attached to barracks, and hand catch refers to mosquitos caught by expert negroes within buildings, by means of a small killing vial. All counts were made daily.

Though the white American is presumed to be more susceptible to infection, his well-screened home, his rather regular habits, and the free use he makes of the dispensaries, protect him amply against ready infection. The cases reported are mostly of men working on night shifts. Negroes and Spaniards show more malaria, due largely to habitual loungings outdoors after dusk, thus exposing themselves to Anopheles bites. The New Gatun high percentage is due to lack of screening (Orenstein, 1912-b). The New Gatun cases, as well as those of negroes in Gatun proper, are only such as presented themselves at the dispensary, and often malaria was a secondary diagnosis, for the patient complained of totally different symptoms. It is the general rule that the first attack of malaria gives the negro considerable fever, whereas subsequent attacks are much milder. Very often a negro may have a good quantity of parasites roaming about in his blood, yet be unconscious of the fact. Such cases do not find their way into the dispensaries, and of course are among our worst enemies, for they allow the spread of the fever. Therefore it may be reasonably supposed that the malarial rate in New Gatun was at least fifty per cent. higher than reported.

The narrowness of the strip of the Canal Zone, its congested labor centers, frequent trains and heavy traffic, added a big factor, that of the spreading of Anopheles from this place to 
other stations. Adults of tarsimaculata have been picked up in passenger and freight cars forty miles from Gatun, and later in the season larvae were found at Balboa and Ancon which upon maturity yielded tarsimaculata. There is no doubt whatever in the writer's mind as to the origin of this new breeding area; the invaders in these swamps of Ancon and Balboa came from the Gatun influx. The writer examined at regular intervals the mosquito catch from Monte Lirio and Frijolles, seven and thirteen miles distant from Gatun, and at first the Anopheles were wholly albimanus and malefactor, but toward the end of February, tarsimaculata was not at all uncommon.

To outline briefly the history of the breeding at Gatun, it was generally supposed by several inspectors that the trouble came from the floating islands and vegetation in Gatun lake. An inspection from a launch revealed nothing. Mr. J. A. Corrigan, the inspector in charge had a totally different idea, and after the others returned without results, he invited them to the actual source of trouble, the salt-marsh north-west of Gatun. How he came to that conclusion is probably explained on the basis that he knew not merely his district, but also the territory just outside of it. At any rate, once well within the thickets in this marsh, all agreed it was as near true to the most authentic descriptions of Hades as could be had.

Nor was this tormenting scourge confined to the marsh. The early part of January, the clerks in the Administration building at Gatun began to place blotters on the seats of their wicker chairs; some claimed this measure only alleviated the discomforts. Colonel Phillips came to investigate, and left the place with an Anopheles clinging to his coat, and this mosquito held on notwithstanding that a ten-mile wind flapped violently the coat. The writer noted on March 20th, a. m., a negro with a female tarsimaculata resting on his coat, and traced it over two hundred yards. In a previous paper (1913) the writer reported having carried A. albimanus into Corozal which had been clinging to his clothes for quite a distance. Anopheles cling more tenaciously to clothing than do Culex.

At the hotel, particularly at night, mosquitos insisted in painfully assisting the men trying to eat. The location of the door, as well as the fact that it was practically continuously open during the hours when mosquito activity commenced, 
was the real cause of so many of these pests being within. Once in, and finding the electric lights too intense, they remained under the tables. The Y. M. C. A., close to the hotel was relatively free from mosquitos, due to the fact that the door was not situated the same as the hotel door.

It is impossible to estimate the number of mosquitos which paid daily visits to Gatun, and were any true statement made, it would appear fictitious. At the cement shed, close to the breeding place, cob-webs were so heavily loaded with mosquitos that they sagged and were torn in places, (Zetek 1913-b). The presence of so many mosquitos in these cob-webs is explainable by the fact that mosquitos inside of the building always aim to get out at dawn, at least so has been found to be the case over and again, and there being many cob-webs about the windows, large numbers of mosquitos were caught in them. The spiders do not seem to care for mosquitos. To be stranded at the breeding place was a most painful trial, though unusually fruitful in results.

Sweep-net catches showed mosquitos harboring in the low grass whenever the day was foggy or cloudy, but in clear, warm days, but few were found in such grass. Cracks in the soil were found to harbor Anopheles (also black flies). The shaking of bushes near the breeding place frightened away veritable clouds of Anopheles and Aedes. By placing a negro within a mosquito bar net having one side slightly raised and exposing same during dusk (at the breeding place), there were attracted into that net a trifle over three thousand Anopheles, actual count, which represents about a hundred mosquitos entering the net each minute.

Ocular inspection at the right time of the day-at dusk and during dawn-sufficed to detect a noticeable flight of the mosquitos to Gatun from the salt-marsh. Marking the adults with anilin dyes was done only to clinch the facts, to prove beyond all doubt that the mosquitos seen in flight really were bound for Gatun.

The remedial measures pursued to stop this immense breeding were the digging of two drainage ditches and the reclamation of the marsh by hydraulic fill. The trees and jungle at the peninsula fronting the breeding area were cut and burned over by February 4, 1913 and the smoke and the destruction of a large area of shelter were effective in reducing for the 
pipe was moved in the direction of ditch "B." In places the pupae were so thick as to give the appearance of heavy moss. At regular periods large areas of very young larvae were encountered, indicating that breeding was far from stopped. On March 13th, about four gallons of top minnows were taken from the old French Canal and transferred to the marsh, but these fish left no record of having in any way checked the numbers of larvæ.

The chlorine.content of the water exceeded at times that of sea-water. When the fine silt began to mix with the water, the beginning of the end was plainly in view. Ditch " $\mathrm{B}$ " was deepened, while "A" was closed. This allowed the fill to proceed toward "B." By the end of June the paucity of larvæ was very noticeable and during July and the following months no breeding was encountered.

\section{B. LIFE HISTORY.}

1. The Immature Stages: The flight experiments and the daily examination of thousands of mosquitos, allowed but little time for a study of larvæ and pupæ. The duration of the pre-adult stages of $A$. tarsimaculata were found to be as follows: egg-instar fifteen to twenty-four hours; larval stage from four to five days; pupal stage from two to three days; or, for the entire period, seven to nine days. Aedes taeniorhynchus from the same locality matured about a day sooner. No distinguishing markings could be made out in the field with a 10x lens which separate true albimanus from tarsimaculata. The pupæ of the latter appeared to be darker in color, but from a series of pupæ from other stations, this color difference proved to be valueless. To the sanitary inspector it is enough to group the species into several easily recognized divisions. Thus on the Canal Zone, the Anophelenes may be divided into (1) the albimanus group; (2) the malefactor group; and (3) the pseudopunctipennis group.

Larvæ orient themselves readily to regions of shade. Sunlight, or any highly intense light, which may shine directly upon a mass of larvæ, causes great commotion among them, which excitement finally ends in shaded portions of the pool. A similar reaction ensues when a film of vegetable oil reaches larvæ. There is also a decided reaction to shadows that pass 
over a body of larvæ, in this case the movement is downward and not transverse. They remain quietly on the bottom for several minutes. Pupæ are the more restless, and cannot remain below the surface as long as do the larvæ. When the pipe line dredge poured silt into the marsh, larvæ were not found in the silt-laden waters, but always just in front of it. When silt became generally distributed, the reduction of larvæ was very pronounced.

At the laboratory several tests were made to learn the reactions to such stimuli as gases passed over the surface of water containing larvæ. A large basin was used; it contained pupæ and larvæ and water from the breeding place. Three glass jets of about $1 \mathrm{~mm}$. diameter and $2 \mathrm{~cm}$. apart, were placed $2.5 \mathrm{~cm}$. above the surface of the water, at the middle of the basin, and in such a way that the streams of gases passing through these jets shall pass parallel to the surface of the water. The gases used were oxygen, carbon-dioxide, hydrogen sulphide and chlorine. Each test consisted of five minutes of constant stream of gas. Two hours elapsed between each test. There was no marked reaction toward oxygen. When $\mathrm{CO}_{2}$ was used, no reaction was noted during the first two minutes, but after that all larvæ slowly separated toward the two ends. This test was repeated several times, varying each time the light at both ends, but the reactions were alike. Similar separation occurred with $\mathrm{H}_{2} \mathrm{~S}$ and $\mathrm{Cl}$, being most marked and almost instantaneous with the latter.

Similar experiments were made, excepting that the gases were allowed to diffuse in the water. The modifications in apparatus consisted in the addition of a small fan-shaped jet near each end through which fresh water flowed into the basin; opposite these two jets were small outlets for overflows. At the middle was a small fan-shaped jet through which the gasses passed. All gases were introduced for periods of five minutes, and a new lot of larvæ and water were used for each test. The flow of gas was regulated so as not to agitate the water. The number of larvæ were never less than a hundred.

When oxygen was introduced, the larvæ nearest the stream of gas became more active, but except for this, no other reaction was observed. With carbon-dioxide the larvæ separated for both ends, and at the end of 4.5 minutes they wriggled to the 
bottom where they remained almost motionless. None came to the surface until thirty minutes after the stream was cut off. Chlorine and bromine gases had very decided effects; immediately the gas was introduced the larvæ began to wriggle violently, and after the first minute slowly lost all motion. Some remained at the surface, others at the bottom. Five minutes of either gas was sufficient to kill all larvæ at the end of one hour and ten minutes exposure in the water.

Successful introduction of a gas into water breeding mosquitos would kill all larvæ in short time and would prove a valuable agent in the reduction of breeding. But from the fact that the average native is not over-careful as to the kind of water he drinks, extreme caution must be used in the gas used. Under certain conditions it would be quite effective to introduce suitable electrodes into saline waters breeding mosquitos and destroy these by the liberation of chlorine gas through electrolysis.

2. The Adult Stage: Elsewhere it had been stated that the food of the female Anophe'es transmitting malaria is probably restricted to human blood and that this exclusive diet was reached by a gradual adaptation and restriction to the human race, covering probably centuries of time, and probably at some period thereof has been accelerated by the introduction and establishment of the malarial parasite. That such mosquitos are restricting themselves to inhabited regions is clearly in evidence on the Canal Zone. Regions away from habitations have habitats which are identical in every respect to those on the Zone which breed albimanus, and yet they are sterile as to such species. Nor are there adults of such species in the bush nearby. In the malarial mosquitos this restricted adaptation is not as complete as that of the yellow-fever mosquito, Aedes calopus Meigen, but an unmistakable trend in the direction of greater restriction is plainly in evidence. Females predominate by great percentage in all traps attached to buildings and in mosquitos caught inside of buildings. The proportion is as high as $250: 1$. Smears of the stomach contents of over a hundred males caught in Gatun barracks showed no case of a human blood meal. It is also quite probable that if males did suck human blood, some member of the sanitary corps would have noticed instances of it. It seems that the male Anopheles 
does not suck human blood. Occasionally females are found with the antennæ quite plumose, so much so as to resemble males at first sight. Therefore all supposed males seen sucking blood should be caught and examined carefully as to sex.

Observations at Gatun suggest that a blood meal is necessary before normal oviposition can take place. Darling (1910 p.27), records a case of a virgin Aedes calopus with developed ova after it had but one meal. In another place he states that the eggs from virgins are sterile. In the laboratory, freshly emerged tarsimaculata did not copulate during the first two days when deprived of all food, but a few did so on the third day. When a meal was given the first day, copulation was noted early the next day. Dissection of females three days old showed the ovaries most developed in those individuals which had had food. The daily flights to Gatun were in quest of food, and the morning return flight was most probably for the purpose of oviposition. That it was not for shelter is evident since abundant shelter is found under buildings in Gatun, and this shelter was made use of by large numbers of mosquitos. It appears from the few observations made that copulation takes place in the air, during the morning return flight. Occasional males were picked up in the flight to Gatun, but always near the breeding place and during the morning return flight. More males were noted at the return flight than in the evening one.

Laboratory experiments indicate that after a good blood meal an Anopheles does not bite again until after the pellet of waste is evacuated. When no blood meal was available, Anopheles were seen to suck water. Usually after a meal on ripe banana, a drink of water was taken.

Kept in a screen cage of about two cubic feet, and controlling light, heat and moisture as much as possible, with a few crushed raisins as food, adult tarsimaculata were kept alive twenty-six days. How long they may live outdoors cannot be said, however, it appears certain that they cannot be as long-lived as are some of the mosquitos of colder climate. The severity of heat and moisture lower the life duration period, and the depreciation brought about by this check is counterbalanced by increased reproduction and more rapid development of the pre-adult stages. 
Reference was made to the habits of the night-jars*, which appeared when mosquitos were in flight and fed on them. The numbers thus eaten are not large. The main food of these birds consists of hemiptera and ants. Bats were noted only sparsely, while tree frogs, spiders and lizards were seen frequently catching Anopheles. By far the most destructive agent in the mosquito's environment is man and his various measures.

The effect of oils rubbed on the skin, as a repellent to Anopheles, was tried out at the marsh, but the negroes who smeared themselves concluded the oils were more bothersome than the mosquitos. Pyrethrum was also burned. The method used was to place a negro into each of the four mosquito-bar nets and after about two hours of exposure, the nets were tied at the bottoms, placed into a closed room and the mosquitos killed with sulphur dioxide. The tent with burning pyrethrum was the furthest away so that the wind would not carry the fumes to the other tents.

\begin{tabular}{|c|c|c|c|c|}
\hline & $\begin{array}{c}\text { Oil of } \\
\text { Sassafras }\end{array}$ & $\begin{array}{l}\text { Oil of } \\
\text { Creosote }\end{array}$ & Pyrethrum & Check \\
\hline 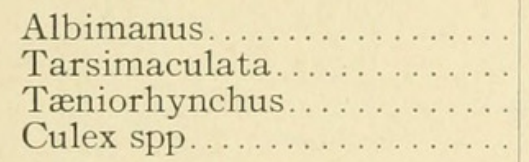 & $\begin{array}{r}6 \\
503 \\
2 \\
19\end{array}$ & $\begin{array}{r}4 \\
163 \\
5 \\
13\end{array}$ & $\begin{array}{r}3 \\
298 \\
2 \\
12\end{array}$ & $\begin{array}{r}5 \\
321 \\
28 \\
69\end{array}$ \\
\hline Total. & 530 & 185 & 315 & 423 \\
\hline
\end{tabular}

The oil of creosote was the most effective repellant, whereas oil of sassafras seemed to attract Anopheles. Reduction was most marked with the culex spp. The men in the nets reported many instances of Anophelenes biting through the film of oil. There is a fruitful field of investigation still open, which should yield a substance with which we may attract thousands of mosquitos, and by the arrangement of traps, destroy these. Experiments on the Zone yielded nothing worth while so far.

* The weight on the stomachs of the four birds killed was: $3.55,3.5,4.05$ and $3.9 \mathrm{gms}$. They contained 49 large yellow ants, 30 pentatomids, 6 coleoptera and a mass of greatly disintegrated insect remains. In the esophagus were found five Anopheles, and in the mouth cavity of one bird were two more. 


\section{BEHAVIOR.}

\section{Flight.}

a. By Direct Observation.

I. The Le Prince Observations: Mr. J. A. Le Prince detailed sixteen sanitary inspectors to report at Gatun on March 28th, 1913, to observe the evening and morning flights. A graphic representation of the positions taken and the facts obtained are given in the following two charts and map. A line of observers was strung on the peninsula and the island, parallel to the old French Canal, intercepting the line of flight of the mosquitos for more than a mile. Four additional observers were stationed along the railroad at and beyond New Gatun.

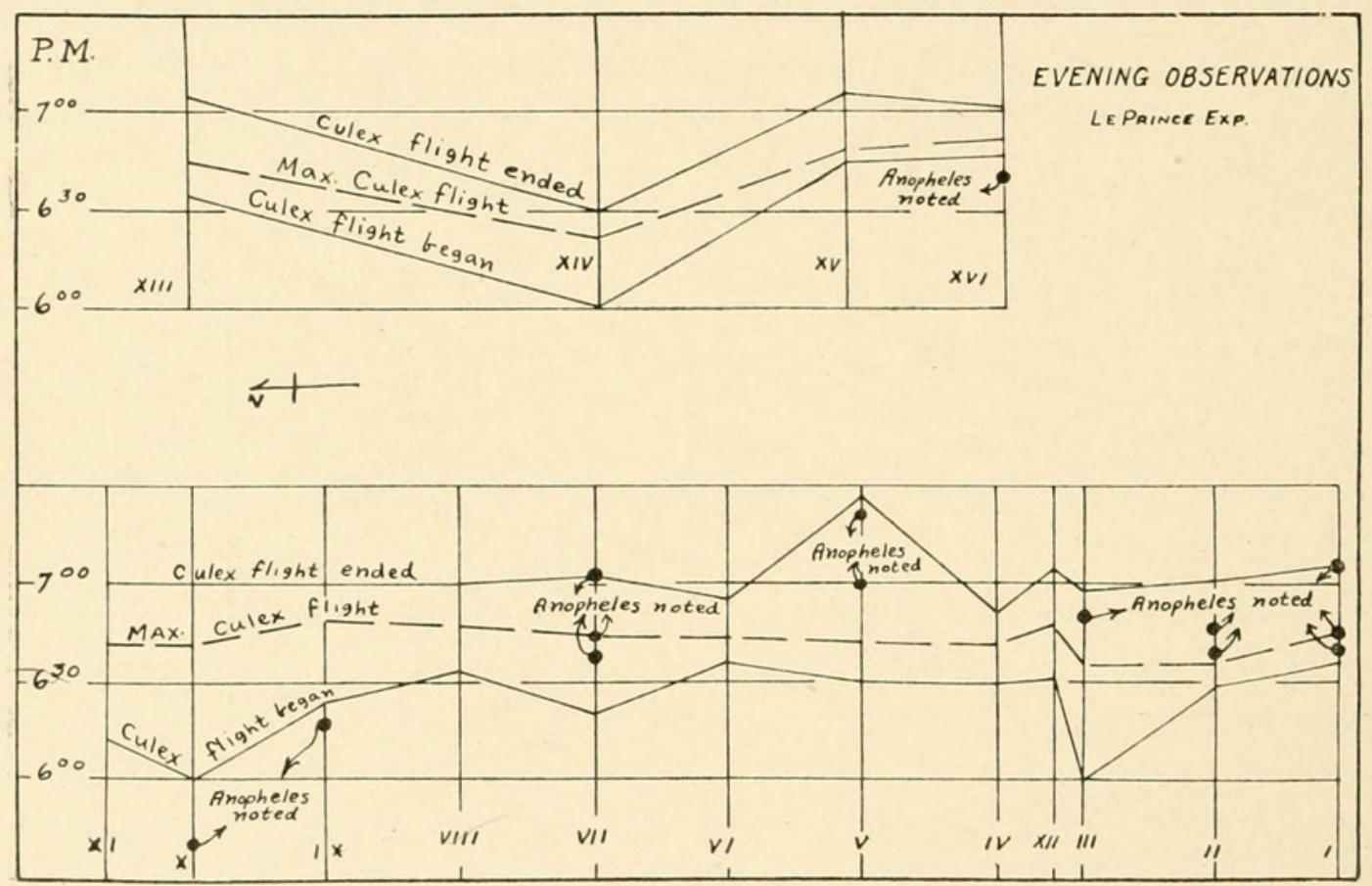

The instructions given were:

To observe (1) when the first culex appeared; (2) when the first Anopheles appeared; (3) when the culex were thickest; (4) when the Anopheles were thickest; (5) when the culex flight ceased; and (6) when the Anopheles flight ceased. The men were at their posts by $5: 30 \mathrm{p}$. m. on the 28 th and by $5: 30$ a. m. on the 29 th, early enough not to miss anything.

The charts show a fairly even flight along the line parallel to the breeding place. The evening flight began at a little 
after six p. m., its maximum at about 6:40 p. m., and was completed by about 7:00 p. m. The morning flights began at about 5:55 a. m., the maximum return Anophelene flight at about $6: 05 \mathrm{a}$. $\mathrm{m}$., ending at $6: 25 \mathrm{a} . \mathrm{m}$. The Anophelene return flight ended sooner than did that of taniorhynchus. The morning flight is shorter in duration than the evening one, is marked with greater precision than the evening one and takes place higher above the ground than during the evening.

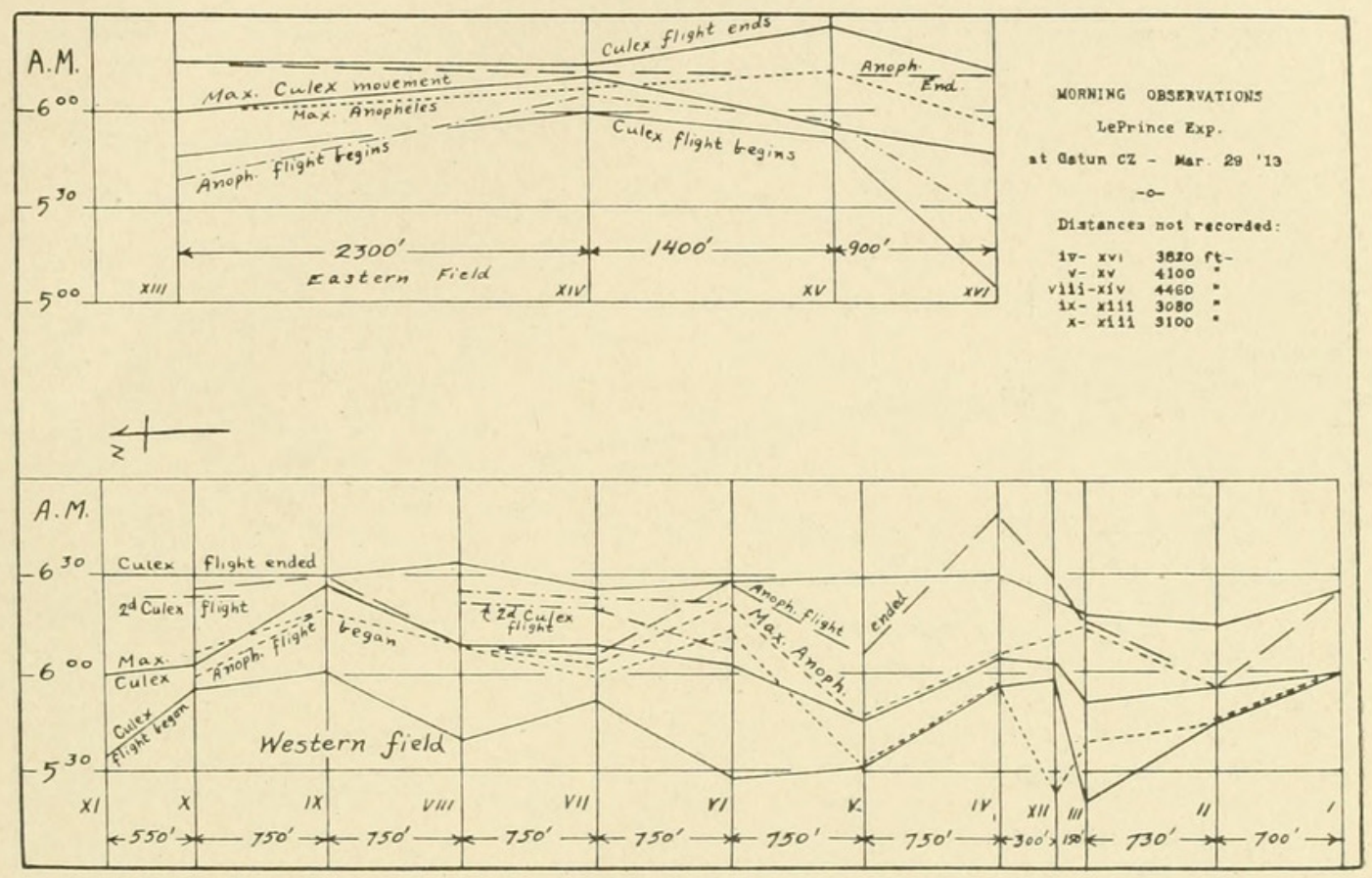

The important facts obtained during this extensive experiment were: 1, the finding of blood in mosquitos of the return flight; 2, finding of males in the return flight; and 3 , the definite mechanical adjustment to light intensity. More such experiments as these of Mr. Le Prince are needed; they yield more useful data than a lot of learned speculations over a few ideas.

II. Observations from Boats: While mosquitos were being trapped at the swamp, two inspectors in a small row boat moved up and down the old French Canal, and by lying on the bottom so as to have the sky for a background, one of the men would observe the mosquitos as they flew past. This method was the first used to learn that a flight actually was taking place. 


\section{b. Demonstration of Flight.}

I. The Staining and Recovery of Marked Mosquitos: In his previous paper (1913-a) the writer devoted considerable space to the need-of collecting large quantities of larvæ and pupæ and how these should be treated to yield a maximum amount of adults. At that time this was the only way adult mosquitos could be had in sufficiently large numbers. At Gatun, as already stated, the conditions met with presented a great improvement over this tedious and often disappointing method.

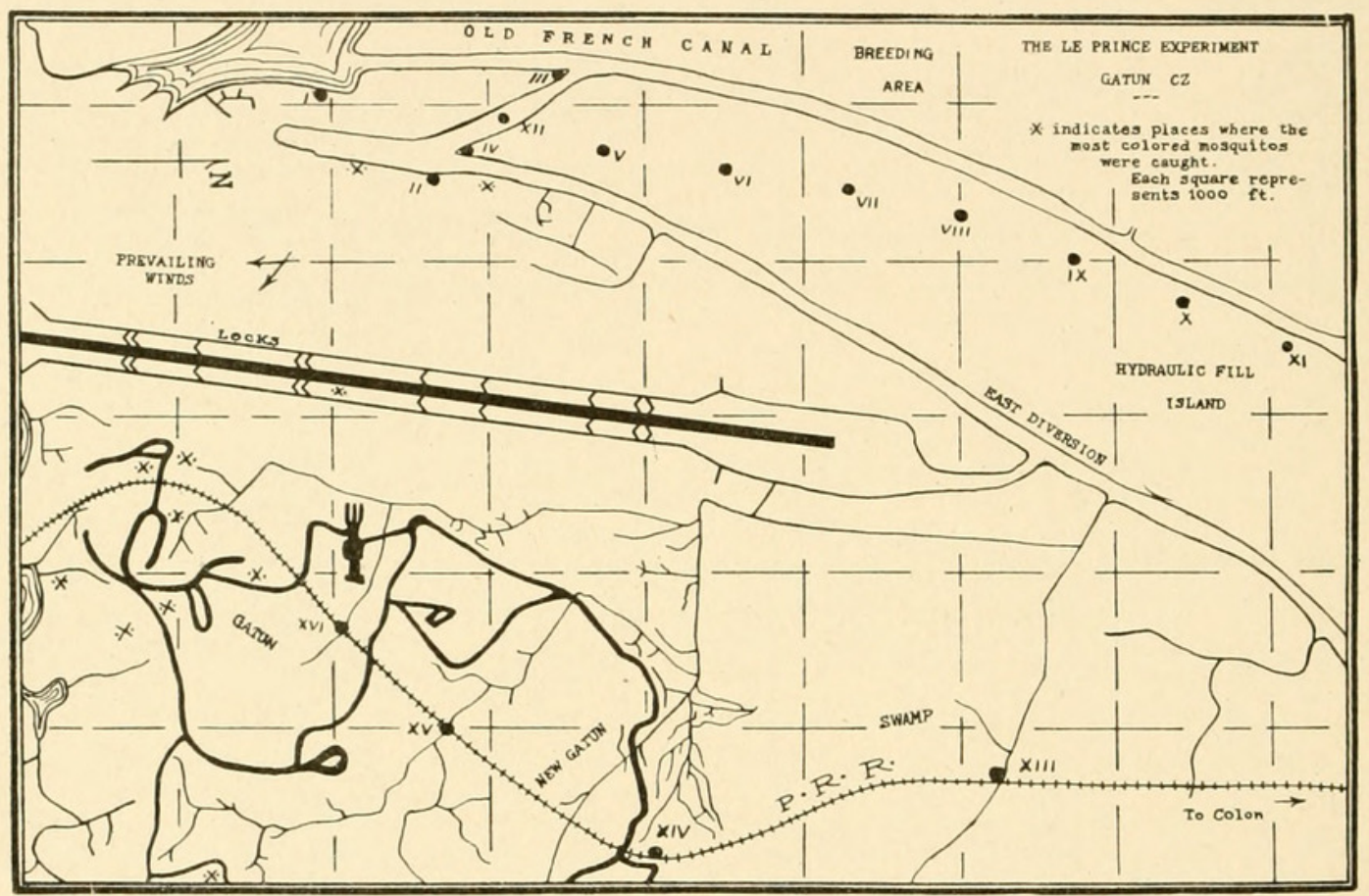

The Anophelenes and Aedes taniorhynchus were so prolific that several thousand could be trapped within an hour. The special advantages of this, aside from the saving of time and expense, were, (1), that the adults matured in their natural environment and not in breeding cages; (2) they were an integral part of the hordes which would begin that same night their hasty journey to Gatun; (3) they were caught the same late afternoon they were to be liberated and could be set free at the exact moment that the flight began. The only unnatural feature was the addition of the tiny speck of anilin dye, but this can hardly produce much inconvenience to the mosquito since the spray used was extremely fine. If the spray had been very coarse and prolonged, it is easy to see how the speck of dye would cause mechanical irritation. 
Mosquito bar nets were stretched out at the breeding place, three sides of which were in close contact with the ground while the remaining side was raised about a foot or so from the ground. At about 5:00 p. m. a negro was placed inside of each net, with instructions to prevent as far as possible mosquitos biting him. Within an hour Mr. Negro shared his net with a thousand or more noisy mosquitos. More mosquitos entered nets when these were kept dark.

The noise made by these dens of voracious, unrestful culicids, their persistent, unceasing attacks, and the endurance of the willing and patient negroes, are things that can never be forgotten by those who had witnessed them.

After having the nets full of mosquitos, the next step was to spray them. The usual vaseline nebulizer was used, and a 1 : 100 solution of anilin dye in water sufficed to give enough color to the mosquito so as to be easily recognized if found later on. Spraying was facilitated by illumination from the outside. Two net-fulls of mosquitos were killed after sprayed and when tested showed a percentage of 98 positive. Within fifteen minutes after spraying the nets were inverted and the mosquitos allowed all the freedom they cared for. It was assumed that at the end of this period a sufficient number would be in condition to take part in the flight to Gatun.

At the same time similar nets were placed opposite the breeding place and elsewhere, with men, dog or hens as bait, and the mosquitos thus caught were examined for color. The results are given elsewhere. It is well to state here that due to the fan-like spreading of mosquitos from the breeding place, and the unusually well-screened and protected homes in Gatun, one cannot expect a large number of colored mosquitos in the houses. The proportion of colored mosquitos to non-stained ones is probably as high as one to three hundred.

The following table gives the time, numbers, etc. of the marked mosquitos liberated. The direction, velocity and trend of the wind at the time of liberation is also indicated. Attention is called to the fact that the winds at such hours were generally of high velocity - a fact which should not be forgotten when one reads so many accounts that mosquitos do not fly when the winds exceed four miles per hour. Such speculative deductions are the natural results of looking upon 
a mosquito from the standpoint of man's level, rather than interpreting its behavior from a dipterous standpoint.

L. Liberated at Salt-marsh, 1913.

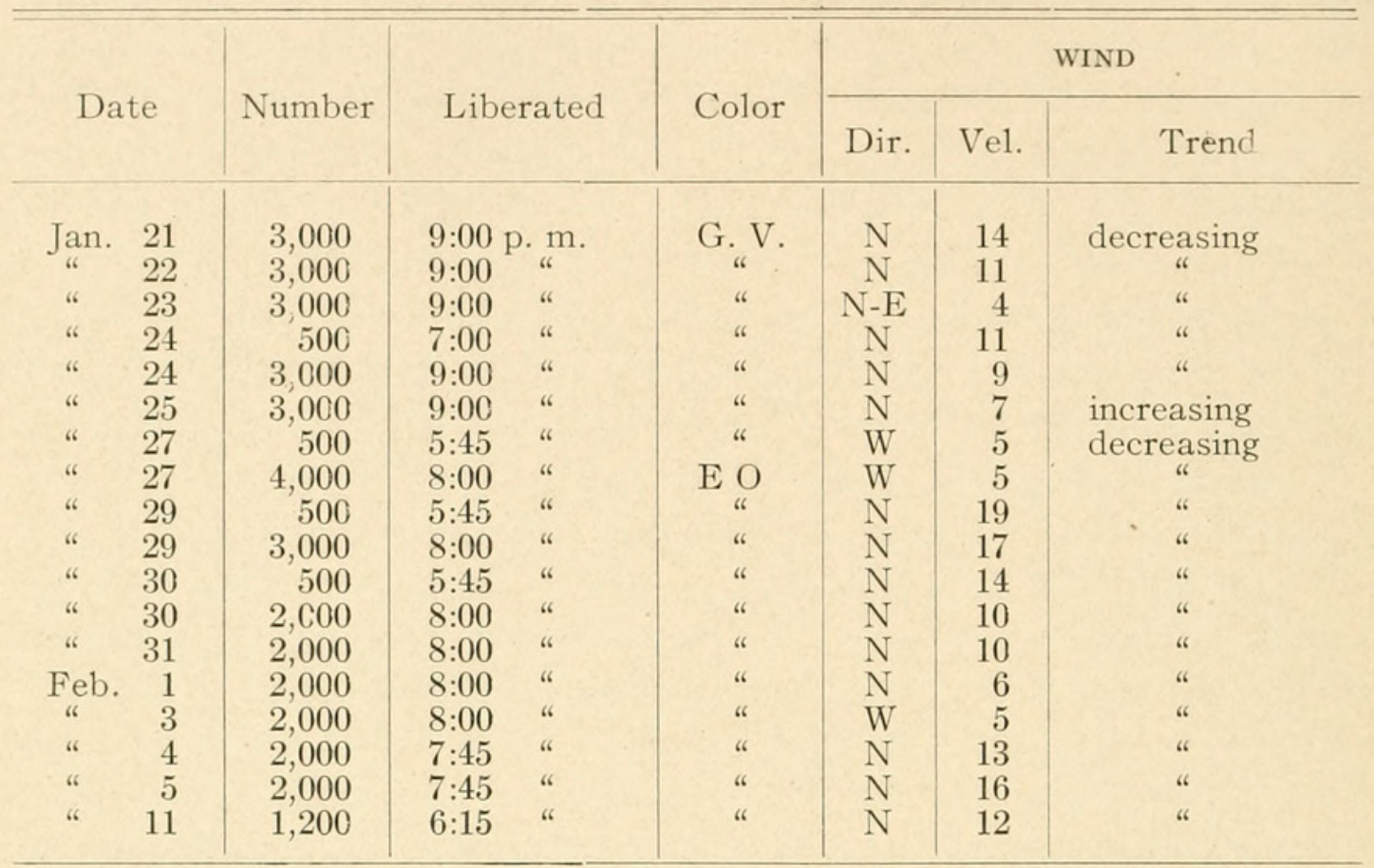

Total liberated, 37,200 . G. V.=Gentian violet; Eo=Eosine.

The above table shows that the actual ideal was not followed, i. e., all liberations should have been done before 6:00 p. m. However, it will be seen from the data of recovered mosquitos, that the first colored ones found were on the 24th of January, and the first lot of colored mosquitos liberated was on the 21st. But these did not participate in the flight to Gatun until the evening of the 22d. Therefore, they entered the buildings either that same evening or the next day. In future experimentations of this sort, marked mosquitos should be liberated just when the flight is to commence.

All mosquitos caught in Gatun and New Gatun and occasional lots from Spillway Camp, New Frijolles, Monte Lirio and Camp Purdum, were tested for color, the method used being the same as in the author's previous paper (1913-a). Collection of adults was accomplished in the following manner: (1) a daily search through all buildings, made by expert negroes equipped with a wide-mouth vial containing a cotton plug saturated with chloroform; (2) by means of the "C. H. Bath" mosquito trap attached to barracks; and (3) by placing mosquito 
bar nets under buildings with negroes as bait. A table of recovered mosquitos is inserted here:

M. Colored Mosquitos Recovered at Gatun, C. Z.

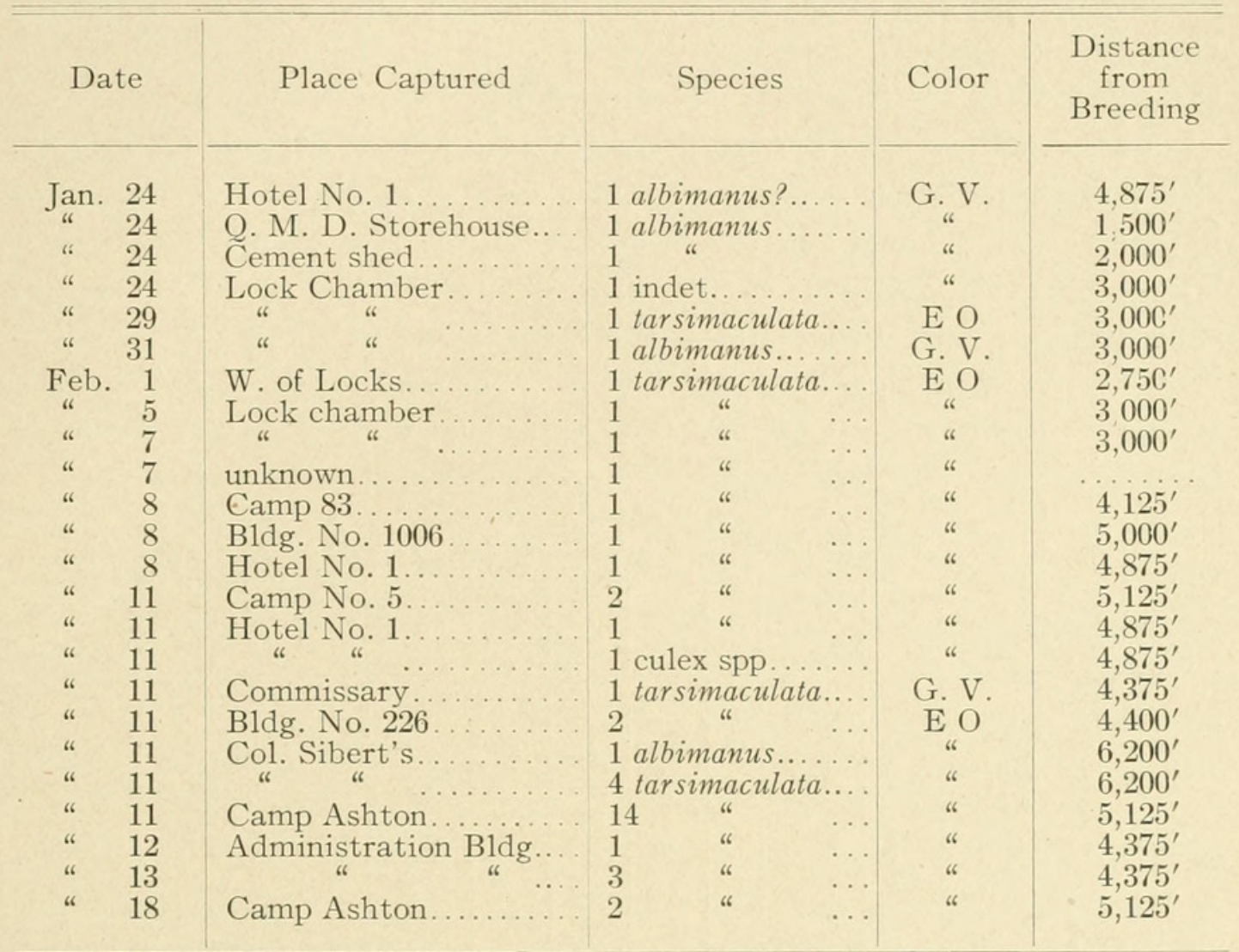

Total: albimanus 5 ; tarsimaculata 38 ; culex sp. 1 ; indet. 1.

45 recovered $-6 \mathrm{G}$. V. and 39 Eo.

Attention is called to the finding of a violet colored mosquito on the 11th of February, fourteen days after this stain was last used. It is hoped an opportunity may present itself to some one to be able to stain no less than twenty thousand mosquitos one night, and two weeks or so later to stain a similar quantity, using a different stain each time. By careful recovery of mosquitos in the townsite and environs, one should get some idea as to the longevity of individuals.

The number of recovered mosquitos is not phenomenally large, but it is conclusive proof that the mosquitos seen flying from the marsh toward Gatun, actually entered that town. About sixty specimens were found which showed a very faint tinge of color when the testing solution was applied, but these were not considered; only specimens which showed a decided color reaction have been incorporated in the table. When 
nets which had been used for staining mosquitos were to be used under buildings, a careful search was made to eliminate any dead, colored mosquitos which might be entangled in the meshes of the net; and if by any chance a hard-dried mosquito was found among a fresh lot, it was always discarded. In this way it is believed all chance errors were eliminated.

From Feb. 8 to 21, mosquito bar nets were placed at several sites, with negroes again as bait, assisted at times by dogs and hens. During these trials 173 colored mosquitos were recovered. Those near the marsh do not figure in the table of recovered mosquitos. The following table presents the data for twentyfour separate nets, during six days. The Anopheles take mostly to men, not merely because of larger surface area, but because these insects prefer human beings to dogs or hens.

N. Mosquitos Caught in Tents, 1913.

\begin{tabular}{|c|c|c|c|c|c|c|c|c|}
\hline Locality & Feb. & Bait & A & $\mathrm{T}$ & TE & $\mathrm{C}$ & Total & Recovered \\
\hline ydraulic Fill. & 8 & Hen & & 12 & 1 & 6 & 19 & e \\
\hline " & 8 & & 7 & 34 & 85 & 53 & 48 & T-re \\
\hline “ & 8 & & 14 & 64 & 41 & 76 & & 21 T-res \\
\hline Peninsula & 8 & Hen & & 23 & & 9 & 32 & $1 \mathrm{C}$-re \\
\hline . & 8 & Dog & & 5 & $\ddot{4}$ & 9 & & \\
\hline $\mathrm{n}^{2}$ & 8 & Man & 2 & 273 & 10 & 15 & 300 & 7 T-red; 2 C-red; \\
\hline Hydraulic Fill. & 10 & Hen & 1 & 108 & 11 & 10 & 130 & -red;1T-blue \\
\hline (1) & 10 & Man & 6 & 58 & 35 & 60 & & 8 C-red; \\
\hline " & 10 & “ & 9 & 578 & 12 & 20 & 619 & 22 T-red; 4 C-red; \\
\hline eninsula. . & 10 & Hen & & 2 & 1 & & 3 & \\
\hline$"$ & 10 & Do & & 9 & 1 & 2 & 12 & C-red \\
\hline “ & 1 & $\mathrm{M}$ & & 5 & 3 & 3 & & \\
\hline 1 Sibe & 1 & Man & 1 & 7 & 46 & 8 & 6 & T-red \\
\hline & 1 & " & & & 3 & & 1 & \\
\hline te & 1 & " & 1 & 69 & 5 & 1 & 76 & $4 \mathrm{~T}-\mathrm{r}$ \\
\hline “ & 1 & " & 6 & & 64 & 48 & & $28 \mathrm{~T}$ \\
\hline 1 minictution & $1:$ & " & 1 & 148 & 20 & 8 & 177 & 1 T-red \\
\hline Col. Sibert's. & 1 & " & & 2 & 4 & $\frac{2}{5}$ & 8 & none \\
\hline Adm & $1:$ & “ & 3 & 42 & 1 & $\begin{array}{l}5 \\
6\end{array}$ & 43 & 3 T-re \\
\hline $\mathrm{H}$ & 14 & “ & 8 & 25 & 27 & 201 & 493 & Rain throughout, \\
\hline & 14 & “ & 4 & 278 & 14 & 168 & 454 & heavy at $7: 00 \mathrm{p}$. \\
\hline & 14 & 4 & & 51 & 2 & 27 & 80 & Note abundance of \\
\hline $\mathrm{Ad}$ & 14 & & & 22 & 1 & 13 & 36 & $\begin{array}{l}\text { culex,mostly Mansonia } \\
\text { titillans. }\end{array}$ \\
\hline
\end{tabular}

Time: 8th-11th, inc1. from 5:00 to 8:00 p. m.; 12th, 5:00-6:15 p. m.; 12th Admin. bldg. and Sibert's, 6:00-8:00 p. m.; 15th, 5:00-7:00 p. m. A=albimanus; T=tarsimaculata; $\mathrm{TE}=$ taniorhynchus; $\mathrm{C}=$ Culex $\mathrm{spp}$. 
About fifty per cent of the mosquitos in the nets having dogs or hens as bait, showed blood meals, but there is no way of telling whose blood it might be. In one net, a patient negro combatted no less than fifteen thousand sand-flies! Horseflies occasionally appeared in nets.

II. Quimby's Intercepting Planes: Mr. E. Frederic Quimby, a Division Sanitary Inspector, invented and had patented a contrivance by means of which he could detect the direction of flight of mosquitos. In principal his apparatus is much like that used in Massachusetts to trap young caterpillars carried by the wind. Haskell (1913) described the apparatus and the claims given to it by the inventor.

The scheme consists of a metal frame, holding four equal plates of glass, about a foot square each, at right angles to each other from a common vertical. The framework is mounted on a tripod which can be adjusted for height. The plates are smeared with a thin coating of transparent tanglefoot when in use.

The data of his tests are abstracted from his reports to the Chief Sanitary Inspector, and are graphically represented in the following plate. In every instance the instrument was set up at places where flight of mosquitos was known to be occurring. Thus far there is very little data on hand to validate the farreaching conclusions made by the inventor, however, in making this statement the writer does not wish to convey the idea that the apparatus is no good. The principal is right, and all it needs is sufficient experimentation to perfect it. If several instruments were set up and worked without man's presence, the resulting catch would give valuable clues as to the direction of the breeding place from the town-site. Once the instrument is known to be fairly accurate, its use may become general in indicating those areas about a given town-site which require thorough sanitation, and the elimination from control of areas suspected as dangerous but which the experimental data shows relatively safe.

Referring now to the diagrams, the dots represent mosquitos actually caught on the sides nearest which these appear, and the arrows indicate the direction of the wind at the time. With a wind of 19 miles per hour at Mount Hope, "A," one mosquito was found as indicated, and the conclusion was at 
once reached that the breeding place was to the south-east of the instrument. But that same evening, the same place and but an hour later, the wind increased to 25 miles per hour, and as is shown in "B," there were seven mosquitos caught on the north side of the east plane! If the conclusion based on the single specimen in "A" was correct, then the seven mosquitos under " $\mathrm{B}$ " indicate a breeding place to the north-east. The discrepancy is due to the fact that the inventor was close to his instrument, to the north-east of it, and mosquitos attracted

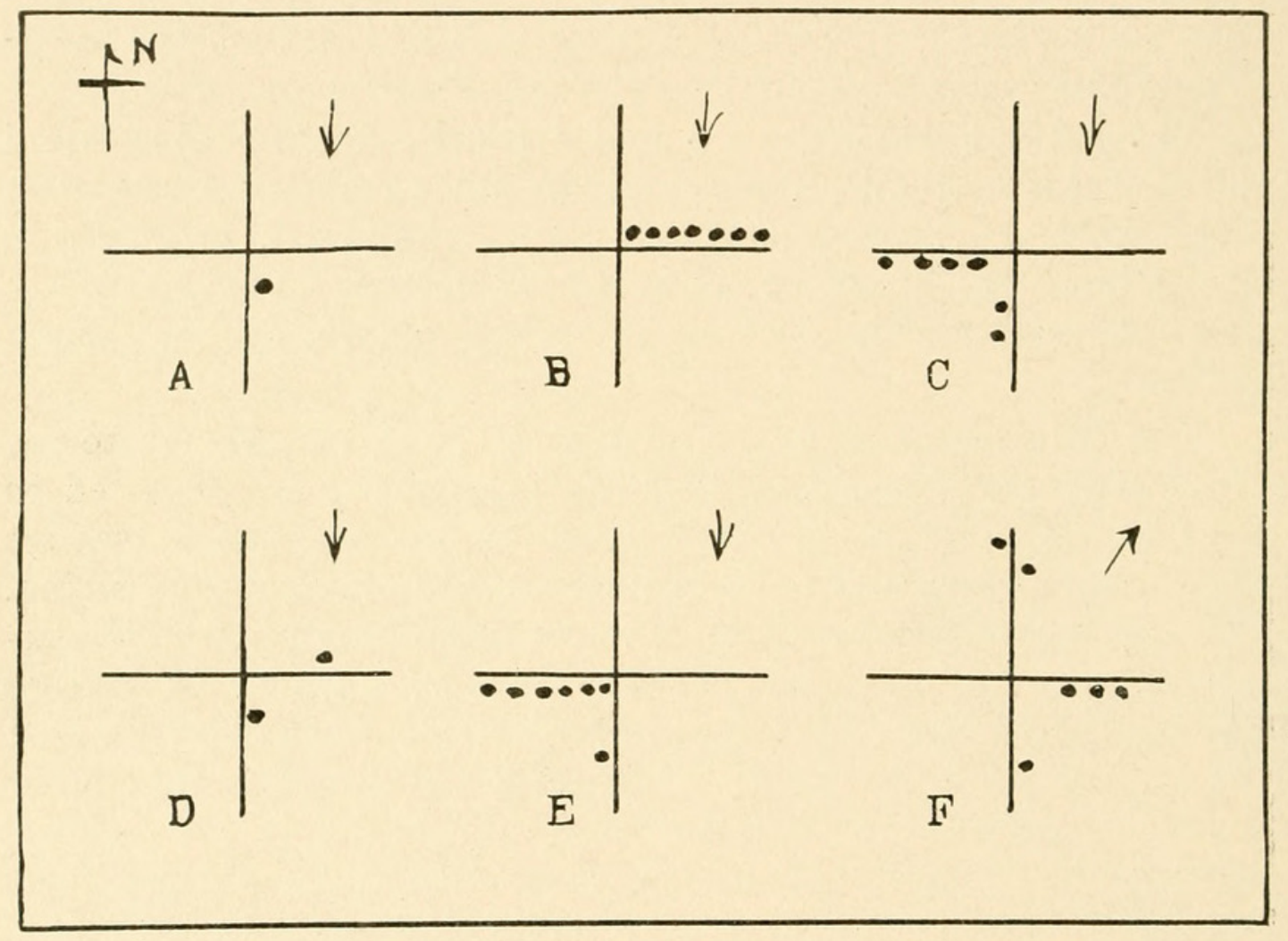

\section{0- Quimby's Data.}

to him were blown against the glass sides due to the high velocity of the wind at that time. Mr. Quimby states in his. report that although mosquito activity was quite observable, it ceased entirely fifteen minutes after the wind increased to twenty-five miles per hour.

The remaining four charts refer to Gatun, and in this case the breeding place was definitely known to be to the west of the instrument. "C" and "E" are evening tests, while "D" and " $\mathrm{F}$ " are morning trials. In case " $\mathrm{F}$ " the wind was from 
the south-west and therefore some irregularities occurred. In all cases the instrument was set about four feet from the ground. More mosquitos were caught during the evening flight. This is because the morning flight takes place higher in the air and the instrument was too low down to intercept it.

Inasmuch as the glass planes are a barrier to the wind, it is worth while to consider the fact when deductions are being made. Our results, covering several years of records, show more mosquitos caught in traps on the leeward of buildings than to windward. Examining Quimby's charts, a similar condition appears to exist. Cases "C" and "E" show more flies on the south side of the west plate. The mosquitos flew at a quarter to the wind, i. e., in a south-easterly direction. Therefore more mosquitos should have been found on the west side of the south plate and the north side of the west plate. The actual catch shows more mosquitos on the lee side, and therefore the breeding place should have been to the south-west and the mosquitos bound for the north-east, which of course was not so.

A few tests were made using copper screen instead of glass, but the tanglefoot produced a coppery odor and verdigris, the results proving negative. A cloth screen, larger in area, would probably yield better results. One instrument is not enough; as they are inexpensive, several dozen should be placed about a suspected area, much on the order that mines are planted across the paths of ocean traffic. And not the least in importance human beings must keep away from these screens as long as the mosquitos are active.

\section{Mosquitos Harboring Under Buildings.}

Since the houses in Gatun are so well screened, and cracks in the floors and walls stopped up, mosquitos enter with much difficulty, the majority of them gaining entrance as doors are opened and closed. It was hardly thought possible that all the mosquitos that flew to Gatun one evening, returned the next morning. Therefore mosquito bar nets were spread under four buildings and a negro placed under each one, equipped with a chloroform-filled killing tube. His instructions were not to impede the entrance of mosquitos and to catch all that entered. 
The data is summarized in the following table. (Alb-albimanus; Tar-tarsimaculata; Tae -teniorhynchus; Tit-Mansonia titillans).

P. Mosquitos Caught Under Buildings, Gatun. DAYTIME CATCH.

\begin{tabular}{|c|c|c|c|c|c|c|c|c|}
\hline \multirow{2}{*}{$\begin{array}{l}\text { Number of } \\
\text { Buildings }\end{array}$} & \multirow{2}{*}{ Days } & \multirow{2}{*}{ Periods } & \multicolumn{2}{|c|}{ Anophelinæ } & \multicolumn{3}{|c|}{ Non-Anophelinæ } & \multirow{2}{*}{ Total } \\
\hline & & & $\mathrm{Alb}$ & Tar & Tae & Tit & Others & \\
\hline \multicolumn{3}{|c|}{$\begin{array}{l}\text { Percent of total..... } \\
\text { Average per period. }\end{array}$} & $\begin{array}{l}37 \\
0.4 \\
0.3\end{array}$ & $\begin{array}{r}11,604 \\
71.7 \\
111.8\end{array}$ & $\begin{array}{c}3,496 \\
21.6 \\
33.7\end{array}$ & $\begin{array}{l}258 \\
1.6 \\
2.5\end{array}$ & $\begin{array}{l}766 \\
4.7 \\
7.4\end{array}$ & 16.161 \\
\hline \multicolumn{3}{|c|}{ Males taken.. } & 1 & 265 & \multicolumn{4}{|c|}{ No count kept } \\
\hline
\end{tabular}

*Four periods lost through invasion of ants.

Thus it is seen that at least 112 Anopheles lingered under each building. Assuming that there are only one hundred buildings in Gatun, then each day there harbored under these houses no less than ten thousand malarial mosquitos. And considering New Gatun, open and unscreened, one must use his imagination freely to arrive at some suitable conclusion. Had it not been for the thorough treatment given in the past to malaria sufferers, and had not a daily search been made in all buildings for mosquitos, then surely the malarial rate would have leapt upward, probably paralyzing for some time the work at this important section.

All males caught were examined microscopically for the presence of blood in the digestive tract, but all tests proved negative. In nearly all females of Anopheles blood was found but since only a very few showed a very recent meal (upon the negro bait), it was reasonable to suppose that the males were taken the night previous. Chironomidæ appeared in great numbers at times, and from April 8th to $12 \mathrm{th}$, out numbered by far the total mosquito catch.

The hourly distribution of mosquitos caught during the night is given in the following two tables. The actual paucity of data permits of no accurate deductions. However, it is significant to note the conspicuous catch of 233 tarsimaculata under 
Colonel Sibert's home, from five to six a. m., the time of maximum activity in mosquito world. The writer recalls that mosquitos were always most active during dusk and dawn, when he was making all-night observations in tents.

Q. At Gatun Locks, February 18 and 19.

\begin{tabular}{|c|c|c|c|c|c|c|c|c|c|c|c|c|c|}
\hline & \multicolumn{13}{|c|}{ Hour Ending at } \\
\hline & \multicolumn{6}{|c|}{ P. M. } & \multicolumn{7}{|c|}{ A. M. } \\
\hline & 7 & 8 & 9 & 10 & 11 & 12 & 1 & 2 & 3 & 4 & 5 & 6 & $\begin{array}{l}\text { తే } \\
0\end{array}$ \\
\hline $\begin{array}{l}\text { albimanus............ } \\
\text { tarsimaculata........ } \\
\text { taniorhynchus....... } \\
\text { culex } s p p \ldots \ldots \ldots \ldots \\
\text { M. titillans.......... }\end{array}$ & $\begin{array}{r}5 \\
40 \\
\cdots \\
- \\
3\end{array}$ & \begin{tabular}{r}
1 \\
18 \\
\hdashline \\
1 \\
2
\end{tabular} & $\begin{array}{l}41 \\
\cdots \\
2 \\
2\end{array}$ & \begin{tabular}{r}
6 \\
95 \\
$\cdots$ \\
\hdashline \\
4
\end{tabular} & \begin{tabular}{r}
4 \\
88 \\
\hdashline \\
1 \\
1
\end{tabular} & $\begin{array}{r}3 \\
47 \\
\cdots \\
\cdots \\
\cdots\end{array}$ & \begin{tabular}{r}
3 \\
51 \\
\hdashline \\
1
\end{tabular} & $\begin{array}{r}1 \\
22\end{array}$ & $\begin{array}{l}19 \\
\cdots \\
\cdots \\
\cdots\end{array}$ & $\begin{array}{l}1 \\
14 \\
\cdots \\
1 \\
1\end{array}$ & $\begin{array}{l}12 \\
\dddot{2} \\
1\end{array}$ & $\begin{array}{r}2 \\
34 \\
2 \\
2 \\
2\end{array}$ & $\begin{array}{r}26 \\
481 \\
2 \\
5 \\
16\end{array}$ \\
\hline $\begin{array}{l}\text { albimanus.......... } \\
\text { tarsimaculata........ } \\
\text { taniorhynchus ...... } \\
\text { culex } s p p \ldots \ldots \ldots \ldots \\
\text { M. titillans........... }\end{array}$ & $\begin{array}{l}1 \\
\cdots \\
\cdots \\
\cdots\end{array}$ & $\begin{array}{r}2 \\
30 \\
\cdots \\
2 \\
6\end{array}$ & $\begin{array}{r}1 \\
27 \\
\cdots \\
2 \\
9\end{array}$ & $\begin{array}{l}13 \\
1 \\
6\end{array}$ & $\begin{array}{l}7 \\
1 \\
1 \\
4\end{array}$ & $\begin{array}{l}8 \\
\cdots \\
1\end{array}$ & $\begin{array}{l}12 \\
i \\
1\end{array}$ & . & $\begin{array}{l}6 \\
\cdots \\
i\end{array}$ & $\begin{array}{l}8 \\
\cdots \\
i\end{array}$ & $\begin{array}{l}1 \\
21 \\
\cdots \\
2 \\
2\end{array}$ & $\begin{array}{r}1 \\
14 \\
1 \\
2 \\
2\end{array}$ & $\begin{array}{r}6 \\
142 \\
1 \\
7 \\
33\end{array}$ \\
\hline
\end{tabular}

R. At Col. Sibert's Home, February 15, 18 and 19.

Hour Ending At

\begin{tabular}{|c|c|c|c|c|c|c|c|c|c|c|c|c|c|}
\hline & \multicolumn{6}{|c|}{ P. M. } & \multicolumn{7}{|c|}{ A. M. } \\
\hline & 7 & 8 & 9 & 10 & 11 & 12 & 1 & 2 & 3 & 4 & 5 & 6 & $\stackrel{\overparen{\pi}}{\stackrel{\pi}{0}}$ \\
\hline 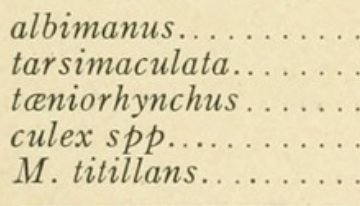 & $\begin{array}{l}1 \\
\cdots \\
4\end{array}$ & $\begin{array}{r}2 \\
2 \\
2 \\
29\end{array}$ & $\begin{array}{l}2 \\
1\end{array}$ & $\begin{array}{r}1 \\
4 \\
4 \\
18\end{array}$ & $\begin{array}{r}3 \\
10 \\
\cdots \\
48\end{array}$ & \begin{tabular}{r}
1 \\
11 \\
\hdashline 1 \\
38
\end{tabular} & $\begin{array}{l}8 \\
\cdots \\
21\end{array}$ & $\begin{array}{r}1 \\
13 \\
\cdots \\
4 \\
24\end{array}$ & $\begin{array}{r}2 \\
5 \\
1 \\
1 \\
26\end{array}$ & \begin{tabular}{l}
2 \\
4 \\
\hdashline \\
2 \\
8
\end{tabular} & $\begin{array}{l}\cdots \\
\cdots \\
\cdots \\
\cdots\end{array}$ & $\begin{array}{l}2 \\
\cdots \\
5\end{array}$ & $\begin{array}{r}9 \\
60 \\
1 \\
14 \\
222\end{array}$ \\
\hline $\begin{array}{l}\text { albimanus........... } \\
\text { tarsimaculata........ } \\
\text { taniorhynchus ....... } \\
\text { culex } s p p \ldots \ldots \ldots \ldots \\
\text { M. titillans......... }\end{array}$ & $\begin{array}{l}2 \\
i \\
1\end{array}$ & $\begin{array}{r}1 \\
4 \\
2 \\
1 \\
11\end{array}$ & $\begin{array}{l}7 \\
2 \\
2 \\
7\end{array}$ & $\begin{array}{l}3 \\
\cdots \\
9 \\
9\end{array}$ & $\begin{array}{r}3 \\
14 \\
1 \\
1 \\
1\end{array}$ & $\begin{array}{l}2 \\
7 \\
1\end{array}$ & $\begin{array}{l}1 \\
i \\
1 \\
1\end{array}$ & $\begin{array}{l}1 \\
\cdots \\
2 \\
2\end{array}$ & $\begin{array}{l}2 \\
3 \\
1 \\
1 \\
4\end{array}$ & $\begin{array}{l}1 \\
2\end{array}$ & \begin{tabular}{r}
1 \\
17 \\
\hdashline \\
1 \\
2
\end{tabular} & $\begin{array}{r}12 \\
233 \\
2 \\
4 \\
4\end{array}$ & $\begin{array}{r}20 \\
292 \\
5 \\
13 \\
57\end{array}$ \\
\hline $\begin{array}{l}\text { albimanus............ } \\
\text { tarsimaculata........ } \\
\text { taniorhynchus ...... } \\
\text { culex } s p p \ldots \ldots \ldots \\
\text { M. titillans........... }\end{array}$ & $\begin{array}{c}1 \\
\cdots \\
3\end{array}$ & $\begin{array}{r}3 \\
78 \\
r \\
1 \\
12\end{array}$ & 17 & $\begin{array}{l}13 \\
\cdots \\
2 \\
2\end{array}$ & $\begin{array}{l}2 \\
2 \\
4 \\
4\end{array}$ & $\begin{array}{r}11 \\
1 \\
17\end{array}$ & 5 & $\begin{array}{r}1 \\
32 \\
1 \\
4\end{array}$ & $\begin{array}{r}4 \\
36 \\
\cdots \\
2 \\
3\end{array}$ & $\begin{array}{l}3 \\
1 \\
14\end{array}$ & $\begin{array}{l}1 \\
22 \\
\cdots \\
\cdots\end{array}$ & $\begin{array}{r}4 \\
2 \\
9 \\
9\end{array}$ & $\begin{array}{r}9 \\
208 \\
2 \\
8 \\
87\end{array}$ \\
\hline
\end{tabular}


The data for the mosquito catch under buildings during the daytime shows that $33.42 \%$ of the total catch is made from $6: 30$ a. m. to $8: 00$ a. m. Several tests were made to note whether the color of the ground had any effect on numbers. White and black ground were used, and the day's catch of the two was taken as $100 \%$. Of this white ground yielded $39.33 \%$ and black ground $60.67 \%$. The question of color of barracks, color of interior, color under houses, location of doors, of windows, etc., have greater importance in the reduction of the numbers of mosquitos than is at first believable, and more definite studies along these lines are needed.

\section{Securing Food and Eating.}

To describe adequately the voracity of the female tarsimaculata or taniorhynchus is to attempt something bordering on the impossible. For indeed language falls short when one tries to narrate what he has witnessed. No matter the time of the day or night, just as soon as one left the boat and entered the jungle of the marsh, hundreds of hungry mosquitos flew forth to warmly welcome the intruder. And if the intruder had come just as dusk appeared, the welcome he received was simply tormenting. Despite all efforts to drive these mosquitos away, he would carry with him no few bites. Laboratory tests showed these two species ready to suck blood when but eighteen hours of age.

There is preference shown to leather leggings and khaki cloth. Since these have a definite odor, probably odor as well as color are the attractive features. Never was there noted an indisposition to eat, and satiation bordered always on gluttony. The proboscis, aided by the palpi, probed assiduously khaki, leather, etc., very often succeeding through cloth. When the proboscis enters the flesh, very little pain is felt, i. e., not nearly so much as some Culex can produce. Frequently the beak is withdrawn and reinserted with increased vigor. Not infrequently females would so gorge themselves with blood that the hind feet could no longer sustain the weight. The normal position of the mosquito is with the body at fortyfive degrees, but when feeding, this position of the mosquito on the person is not of such great importance. Mosquitos were seen hanging from the under side of the arm. When the 
abdomen hangs vertically, the mosquito cannot gorge itself as much as when in other positions. By placing a paper prop under the abdomen, so as to sustain the weight of the body, the mosquito was able to gorge itself to its utter satisfaction.

Leather leggings were rapidly lined with mosquitos. By covering one legging with light colored paper, very few mosquitos alighted thereon. When black paper was used, more mosquitos were attracted. When the leggings were thrown away, mosquitos still alighted on them in hopes of finding flesh. After sprinting, so as to promote perspiration, and then covering the bare feet with white paper, mosquitos alighted in numbers on the paper, but when black paper was used, nearly triple the number of mosquitos appeared. The sox of negros when thrown into the bush were found to be covered with mosquitos. All this tends to show a similarity of odor between khaki, leather and flesh, and that darker colors are preferred to light ones.

At the breeding place, and later confirmed at the laboratory, interesting feeding reflexes were observed. The Anopheles and Aedes were so voracious that their persistence in getting their proboscis into flesh was remarkable. Once inserted, the mosquito became almost insensible to pain or to intense light or heat.

Hitting the mosquito with a pencil was not enough to cause it to fly away. Bright sunlight focused upon it with a mirror was effective only after the stomach was well gorged with blood, and quite likely the mosquito left for other reasons. When heat rays were applied to the abdomen by means of a lens, a mosquito quickly flew away. To continue and learn how far mutilation could proceed, the abdomens of eight mosquitos were quickly severed with fine dissecting scissors. In three cases the mosquitos kept on sucking blood despite the injury. The remaining five flew away, and of these four returned for another suck of blood. This sort of behavior savors of the fictitious, however, it proves how deeply implanted may be a stimulus such as hunger, and how slavishly it is obeyed.

When allowed to feed unmolested, and holding the hand toward the sun, the writer was able to observe the passage of a liquid through the proboscis into the flesh, presumably salivary fluid, and following this, he could see the blood being sucked 
up. Then came a strange performance. From the anal opening squirted out small droplets of clear liquid, slightly alkaline, and which the writer believes may be a part of the salivary fluids which entered the wound. These droplets soon assume a light reddish tinge which gradually increases in depth until blood-red. By allowing these droplets to fall upon a cover glass and examining these microscopically, it was learned that they actually were human blood. Darling (1912, p-14), refers to a similar reflex. In 1902, Schuffner noted the same performance, and probably further investigation will show that the salivary fluid which enters the blood is not for the purpose of preventing coagulation, but rather to flush out and prepare the alimentary tract for the blood meal. Laboratory experiments made by the writer indicate that after an Anopheles has gorged itself with blood, it does not feed again until the pellet of waste had been expelled.

The insect gorges itself with blood until often it increases the weight by two times. Darling (1912, p. 14), gives the weights of several albimanus, his data being:

Bred in laboratory, 24 hours old, midgut empty.

Bred in laboratory, moderate blood feeding.

$0.0008 \mathrm{gms}$

$0.0016 \mathrm{gms}$

Caught in labor cars, much blood and early development of ova ..... 0.0035 gms.

Caught in labor barracks, blood in midgut, no development of ova.. $0.0018 \mathrm{gms}$.

Caught in labor barracks, blood in midgut, no development of ova ... $0.0021 \mathrm{gms}$.

\section{Regarding the Behavior of Anopheles.}

(General)

Behavior is adaptation to the environment. The focus of the environment and the behavior of the organism is the physiological state of the animal - a dynamic condition. External stimuli, if they are to cause change, must enter and alter the existant physiological state. If the stimulus does not produce movement, it may produce a new change in the physiological state. But a given stimulus which produced a certain change, may not produce the same change always. For example, hunger may modify a response.

High humidity, winds, salinity of water, etc., may alter the environment and by so doing, create a condition of stress. The result of all change is relative unstable equilibrium, and a tendency exists to relieve this stress and approach equilibrium. 
This often means collision with unfavorable conditions, and the animal moves away, a negative response. If it copes repeatedly with such new conditions, it must become attuned to these conditions. If it cannot do so, it must give in to that form or association of forms that can become attuned. Successful attunement results in greater hardiness and ability to cope well with other new conditions.

The gradual domestication of A. albimanus is the result of just such collision. The condition today is not the result of some sudden change, but represents gradual attunement. And probably the fact that the breeding at the swamp, which at first was largely albimanus s. s., later changing almost entirely to tarsimaculata, which presented conditions of extreme salinity and a difference in specific gravity, is another demonstration of just such collisions. There probably exists among the total of any species groups of individuals having one or more strains in them which permit them to endure conditions of greater stress. And so we may readily suppose that the transition from true albimanus to the racial variety tarsimaculata is the result of just such existant strains.

\section{(Specific)}

Regarding flight, two definite facts appear; (1), there is a marked flight during dusk and dawn, and (2), this movement stops with almost mechanical precision when there is too much or too little light. The evening flight was always low and deliberate. That of the morning was characterized by haste and took place higher in the air. The factor which determines the height at which the flight occurs is probably humidity. The duration of the flight depends upon the duration of the zone of light of that degree of intensity to which the mosquitos are accustomed to.

Several laboratory experiments were made to determine the reactions of these mosquitos to light. A large number of $A$. tarsimaculata were confined in a large glass jar which was covered with several thicknesses of black paper. The top was covered with a board in which was drilled a one-half inch hole. Upon this cover was placed a lamp chimney with the top of it covered with gauze. 
(a) The apparatus was set up in front of a window. No mosquitos entered the upper chimney until the sun was low and dusk appeared. Then they appeared in large numbers and congregated about the gauze top. At dawn they also appeared on this gauze top, and they attempted to get away.

(b) Repeated, excepting that the chimney was covered with light paper so as to produce within a semi-darkness not far from that of dusk. Apparatus set up in front of window in bright sunlight. Mosquitos entered the top chimney irrespective of time of day. By removing the paper cover, they scrambled to get into the lower dark cage.

(c) Modified by removing the gauze top of the chimney and by adding to this chimney another one. The top chimney and the bottom one were kept dark within. The middle chimney was kept in semi-darkness. Mosquitos entered middle chimney. The wrapping of this was then taken off, thus admitting bright light. The mosquitos flew into the upper dark chimney.

These crude experiments and the field observations show that these mosquitos are attuned to that range of light intensity which occurs during dusk and dawn. When this optimum intensity is increased, the mosquitos become negatively phototropic.

When hungry, mosquitos are positively chemotropic and this stimulus may alter the effects of intense light and lessen greatly those of heat.

During flight the phototropic response is the dominant one. But observations seem to indicate a positive anemotropism, i. e., an orientation with reference to the direction of the wind. The mosquitos seem to fly at a quarter to the wind. The flight at Gatun was more than one mile and was made in one continuous flight. The observations of Celli in Italy that Anopheles do not fly further than from two to three hundred and fifty meters, indicates a different set of conditions existing in Italy than in Panama. One of the very first things to do in malaria sanitation is to learn the species involved, which of these transmit malaria, and then scour the literature for all facts regarding the behavior of the disease-carriers. Then studies should be carried on to learn something definite about the flight factors, and these studies cannot be of value unless the entire environ- 
ment is considered. Such information may indicate the particular places which require strict anti-malarial measures, and may eliminate from thorough treatment certain suspected areas, thus reducing greatly the cost of sanitation.

\section{SUMMARY.}

(1). The study of the behavior of mosquitos has important value to the sanitary inspector in that this study gives him important clues as to the measures to adopt, which areas to control, and where best to locate temporary or permanent camps.

(2). The factors of wind, temperature and humidity are the most important in the adult mosquito environment. The winds at Gatun are relatively high, but they die down considerably as dusk appears.

(3). The salinity of the water equalled that of the ocean, but did not inhibit breeding. Ordinarily, the water of the salt-marsh is greatly evaporated as the dry season advances, and its salt content so increased that mosquito larvæ cannot live therein. However, there was an increase of rains the latter part of 1912 which so diluted the water of that marsh that the subsequent evaporation did not increase the salt content beyond the critical point.

(4). The life cycle of Anopheles tarsimaculata was found to be from seven to nine days.

(5). Direct observations from boats and on land showed a distinct flight of hordes of tarsimaculata and tceniorhynchus toward Gatun, beginning at dusk, and lasting about thirty to forty-five minutes. There was a return flight from Gatun to the breeding place beginning at early dawn and lasting until objects could be easily discerned, about thirty minutes duration. This return flight takes place higher in the air, and is characterized by haste.

(6). The flight to Gatun was experimentally proved by liberating marked mosquitos at the swamp and later recovering them at Gatun.

(7). Copulation probably takes place on the return flight. More males were found near the marsh during the return flight than during the evening flight. 
(8). Mosquitos were found to harbor during the daytime under buildings in Gatun, a low estimate placing the tarsimaculata population under buildings at ten thousand per day.

(9). The tarsimaculata and teniorhynchus exhibited extreme voracity, and would continue to suck blood although placed in direct sunlight. While feeding, the abdomen of several adults was snipped off without causing apparent pain or total cessation of activities.

(10). These mosquitos would alight on a coat hanging on a tree, or in a cast-away pair of leggings. Odor probably is the main impulse, though preference to dark colors is shown. The mosquitos actually were trying to sink their proboscis into the leather and cloth.

(11). Both species, when allowed to feed unmolested, ejected from their anal openings droplets of clear fluid which later became tinged with reddish, finally resulting in pure blood.

(12). Behavior is defined as adaptation to the environment. Successful attunement to the environment infers repeated collisions with unfavorable conditions and successful coping with these conditions. The apparent domestication of albimanus appears to be the result of such attunement brought about through combatting successfully new and adverse conditions.

(13). During flight the phototropic response is dominant. At the breeding place this tropism is often over-ruled by that of hunger. When in flight, the mosquitos seem to adjust themselves with respect to the wind so as to gain the greatest benefit therefrom. 


\section{REFERENCES}

Abbot, Henry L. 1899. Climatology of the Isthmus of Panama, U. S. Dept. Agric. Weather Bur. Publ. 201.

Banks, Chas. S. 1908. A Mosquito which breeds in salt and fresh water. Philippine Journ. Sci., Vol. III, iv; pp. 335-341.

Bath, Chas. H. 1914. Insect Trap. (Description of the trap referred to in this paper.) Canal Record, Vol. VII, No. 25, February 11.

Darling: Dr. S. T. 1910. Studies in Relation to Malaria. Isthmian Canal Comm. Sp. Pub. Wash. D. C.

1912. A Mosquito Larvacide-Disinfectant, and the Methods of its Standardization. Am. Journ. of Publ. Health, Feb.

Dyar, Harr. G. 1913. See under Howard, Dyar and Knab.

Haskell, L. E. 1913. Device for Detecting Flight of Mosquitos. Sci. Amer. 109, No. 5, p. 102 (This is Quimby's apparatus).

Howard, L. O., Dyar, Harr. G., and Knab, Fred. 1913. The Mosquitos of North and Central America and the West Indies. Carnegie Inst., Wash., Vol. I.

Jennings, Allan H. 1908. Mosquitos Destroyed by the Nighthawk. Proc. Ent. Soc. Wash. Vol. X., pp. 61-62.

1912. Some Problems of Mosquito Control in the Tropics. Journ. of Eco. nomic Ent. Vol. V.

Knab, Frederic. 1913. The Species of Anopheles that Transmit Human Malaria. Am. Journ. of Trop. Diseases and Prev. Medicine. Vol. I, No. 1, pp. 33-43.

1913. See under Howard, Dyar and Knab.

LePrince, J. A. 1909. Mosquito Destruction in the Tropics. Journ. Am. Med. Asso. Vol. LI.

1912. Recent Progress in Antimalaria Work, with Special Reference to Anopheles flight as studied on the Isthmus of Panama. Trans. XV, Int. Cong. on Hygiene and Demography. Wash., D. C.

Orenstein Dr. A. J. 1912a. Sanitary Inspection of the Canal Zone. Am. Journ. of Publ. Health. March.

1912b. Screening as an Antimalaria Measure. Engineering Record, June 29.

1912c. Mosquito Catching in Dwellings in the Prophylaxis of Malaria. Am. Journ. Publ. Health. Vol. III, No. 2.

Schuffner, Wm. 1902. Die Beziehungen der Malaria-parasiten zu Mensch und Muecke an der Ostkueste Sumatras. Zschr. fur Hyg. und Insekt. XLI, pp. $89-122$.

de Vogel, W. Th. 1907. Anophelines dan l'eau de mer. Atti della Soc. per gli Studi della Malaria. Vol. VIII.

Zetek, James. Determining the flight of Mosquitos. Ann. Ento. Soc. Am.. Vol. 1912a VI, pp. 5-21.

1913b. Mosquitos and Cobwebs. Journ. Ento. and Zoo. Vol. V, No. 4, p. 208

1913c. Note on the Oviposition of Aedes calopus Meigen. The Can. Ento. Dec. p. 423.

Ancon, Canal Zone, May 30, 1915. 


\section{$2 \mathrm{BHL}$ Biodiversity Heritage Library}

Zetek, James. 1915. "Behavior of Anopheles Albimanus Wiede. and Tarsimaculata Goeldi." Annals of the Entomological Society of America 8, 221-271. https://doi.org/10.1093/aesa/8.3.221.

View This Item Online: https://www.biodiversitylibrary.org/item/43631

DOI: https://doi.org/10.1093/aesa/8.3.221

Permalink: https://www.biodiversitylibrary.org/partpdf/193771

\section{Holding Institution}

Smithsonian Libraries

\section{Sponsored by}

Smithsonian

\section{Copyright \& Reuse}

Copyright Status: NOT_IN_COPYRIGHT

This document was created from content at the Biodiversity Heritage Library, the world's largest open access digital library for biodiversity literature and archives. Visit BHL at https://www.biodiversitylibrary.org. 